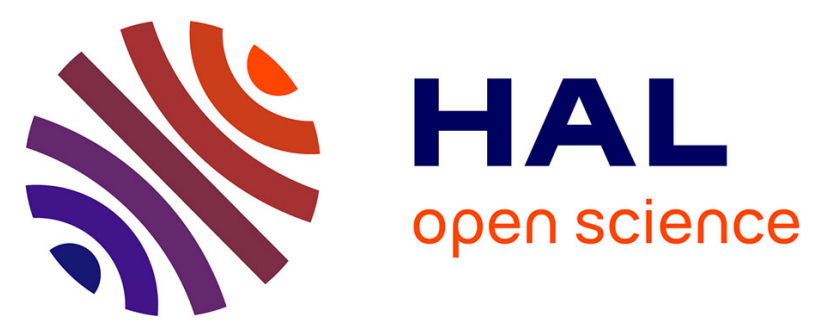

\title{
A Conceptual hydrodynamic model of a geological discontinuity in hard rock aquifers: example of a quartz reef in granitic terrain in South India
}

Benoît Dewandel, Patrick Lachassagne, Faisal K. Zaidi, Subash Chandra

\section{- To cite this version:}

Benoît Dewandel, Patrick Lachassagne, Faisal K. Zaidi, Subash Chandra. A Conceptual hydrodynamic model of a geological discontinuity in hard rock aquifers: example of a quartz reef in granitic terrain in South India. Journal of Hydrology, 2011, 405 (3-4), pp.474-487. 10.1016/j.jhydrol.2011.05.050 . hal-00672876

\section{HAL Id: hal-00672876 https: / hal-brgm.archives-ouvertes.fr/hal-00672876}

Submitted on 22 Feb 2012

HAL is a multi-disciplinary open access archive for the deposit and dissemination of scientific research documents, whether they are published or not. The documents may come from teaching and research institutions in France or abroad, or from public or private research centers.
L'archive ouverte pluridisciplinaire HAL, est destinée au dépôt et à la diffusion de documents scientifiques de niveau recherche, publiés ou non, émanant des établissements d'enseignement et de recherche français ou étrangers, des laboratoires publics ou privés. 


\section{A Conceptual hydrodynamic model of a geological} discontinuity in hard rock aquifers: example of a quartz reef in granitic terrain in South India

6

Benoît DeWANDEL ${ }^{1 *}$, Patrick LACHASSAGNE ${ }^{1,2}$, Faisal K. ZAIDI ${ }^{3,4}$, and Subash ChANDRA ${ }^{2}$ (1)

1- BRGM, Water Division, Resource Assessment, Discontinuous Aquifers Unit, 1039 Rue de Pinville, 34000 Montpellier, France; b.dewandel@brgm.fr; (*Corresponding author). 2- Now at Danone Waters France, 11 av. G. Dupas, BP 87, 74503 Evian-les-Bains Cedex, France; Patrick.lachassagne@danone.com.

3- National Geophysical Research Institute, Indo-French Centre for Groundwater Research, Uppal Road, 500007 Hyderabad, India; schandra75@gmail.com.

4- Now at Department of Geology, College of Science, King Saud University, Riyadh, Kingdom of Saudi Arabia; fk.zaidi@gmail.com.

\section{Abstract}

The structure and hydrodynamic properties of geological discontinuities and of a deeply weathered granite aquifer near these structures are described on the basis of geological, geophysical and hydrodynamic investigations in two sites of South India located along a 2040-metre-wide quartz reef intruding a weathered Archean biotite granite. One of the two sites also comprises a metre-wide dolerite dyke.

Weathering processes appear to be at the origin of fissures development and of a related enhanced local hydraulic conductivity, both in the quartz reef and in the surrounding granite. The weathering profile in the granite (saprolite and fissured layer) is characterized by an abrupt deepening of the weathered layers in the granite near the contact and in the quartz reef itself. Therefore, the weathering profile shows a 'U'-shape geometry with, among others, the verticalization of the granite's fissured layer. The hydraulic conductivity of this verticalized 
layer is on average $5 \times 10^{-6} \mathrm{~m} / \mathrm{s}$ and storativity about $10^{-3}(-)$. The hydraulic conductivity of the fissured quartz is 4 to $6 \times 10^{-6} \mathrm{~m} / \mathrm{s}$ and its storativity about 3 to $5 \times 10^{-4}(-)$. Both media are also characterized by a matrix hydraulic conductivity $\left(10^{-7}\right.$ to $\left.10^{-9} \mathrm{~m} / \mathrm{s}\right)$ and by a significant heterogeneity in hydrodynamic properties that generates preferential flow paths along the subvertical fissures parallel to the reef axis. A special attention has been paid for characterizing this heterogeneity.

The weathering of the dolerite dyke, however, results in a local low hydraulic conductivity, which consequently does not enhance either the thickness of weathered granite layers or its hydraulic conductivity.

The obtained results complete the conceptual hydrogeological model developed for weathered granite aquifers in characterizing the relationships between weathering processes and hydrodynamic properties near geological discontinuities.

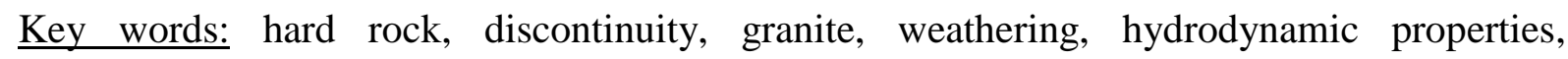
heterogeneity in hydraulic conductivity

\section{Introduction}

Hard rocks (plutonic, metamorphic rocks) form part of the basement of continents and, as such, occupy large areas throughout the World (Africa, South and North America, India, Europe, Asia, Australia, etc.). Groundwater resources in aquifers (HRA) are generally low in terms of available discharge per well (from a few to a few tens of $\mathrm{m}^{3} / \mathrm{h}$ ) compared to those from porous, karst, and volcanic aquifers. However, HRA are geographically widespread and thus well-suited for water supply to scattered populations and small to medium-size towns, or suburbs of larger cities. Their groundwater resources largely contribute to economic development, especially in regions exposed to arid and semiarid climatic conditions where surface-water resources are limited as, for example, in Africa and in India (Uhl and Sharma, 1978; Gustafson and Krásný, 1994; Houston and Lewis, 1998). In such regions, HRA commonly are the only available perennial water resource, supplying the population as well as the agricultural and industrial sectors. However, the knowledge of such aquifers, e.g., their geometry, their hydraulic properties, etc., is currently meagre and needs to be improved.

Significant advances have recently been made in the geological and hydrogeological characterization of such complex aquifers (Omorinbola, 1982; Owoade, 1995; Chilton and Foster, 1995; Taylor and Howard, 2000; Lachassagne et al., 2001; Wyns et al., 2004, 
Maréchal et al., 2004; Dewandel et al., 2006; Ayraud et al., 2008; Courtois et al., 2010; Lachassagne et al., 2011). These studies show that the geometry and the hydrodynamic properties of HRA mainly result from deep weathering processes of the parent rock. Such processes involve biogeochemical hydrolysis of the minerals constituent of the rocks and their mineral transformation under new surface conditions, mainly into clay-rich materials (Tardy, 1971, 1993, 1998; Nahon, 1991). Additionally, these processes are controlled by the regional geodynamical history, which can lead to multiphase weathering profiles because of alternating erosion and weathering phases (Taylor and Howard, 2000; Dewandel et al., 2006).

In granite-type rocks (e.g. granite, gneiss), a typical weathering profile comprises two main stratiform layers sub-parallel to the paleo-surface contemporaneous of the weathering processes (Fig.1; Chilton and Smith-Carrington, 1984; Chilton and Foster, 1995; Wyns et al., 1999 and 2004, Krásný and Sharp, 2007; Maréchal et al., 2007, and others). From the top downward, they are (i) the saprolite layer, a clay-rich material usually characterized by low hydraulic conductivity, and (ii) the fissured layer characterized by dense horizontal fissuring within the first few metres and a depth-decreasing of the sub-horizontal and sub-vertical fissure sets (Howard et al., 1992; Houston and Lewis, 1998; Maréchal et al., 2004; Wyns et al., 2004; Dewandel et al., 2006). This last layer usually assumes the transmissive function of the aquifer. The underlying unfissured and fresh basement is only locally permeable where deep fractures occur, but these conductive zones are much less dense than in the overlying fissured layer and their hydrodynamic properties are highly variable (Pickens et al., 1987; Blomqvist 1990; Walker et al., 2001; Kuusela et al., 2003; Cho et al., 2003). Flow can be fractionalized, i.e. controlled by the orientation of the fracture network (Leveinen et al., 1998).

As a consequence, where the formation is not affected by geological discontinuities, such as faults, veins or dykes, and exposed to deep weathering processes, the saprolite and the fissured layers together make up a composite aquifer of up to $100 \mathrm{~m}$ thick (Fig.1). Hydrogeologically, this medium can be considered as a multilayer system where each layer is characterized by its own specific and quite homogeneous hydrodynamic properties. This relative "homogeneity" allows several practical applications (Lachassagne et al., 2011), among which aquifer budgeting (Maréchal et al., 2006) or the development of Decision Support Tools (Dewandel et al., 2008, 2010). However, where the granite is intruded by quartz, pegmatite or aplite veins, dolerite dykes, or younger granite, or affected by tectonic faults, the layers geometry and their hydrodynamic properties may substantially differ from 
the above-presented conceptual model. Locating such heterogeneities in hard rocks, commonly resulting from lineament analysis and/or geophysical surveys, constitutes the backbone of borehole siting, as major discontinuities and their intersections are often assumed to be strong indicators of a groundwater resource (Mabee et al., 1994; Minor et al., 1995; Sander et al., 1997; Chandra et al., 2006; Sander, 2007). However, such structures do not necessarily give impressive results in terms of well productivity (Sander, 2007); probably because at present their hydrogeological properties in terms of hydrodynamics and geometry are insufficiently understood.

The objective of the present paper is to improve the understanding of the geometry and hydrodynamic properties of such geological discontinuities, through the case-study of a 20 to 40-metre-thick quartz vein intruding granite that was exposed to deep weathering processes. This work has led to a 3-D conceptual hydrogeological model of this structure, on the basis of geological and geophysical surveys, and hydraulic tests carried out on two pilot sites equipped with a total of 21 boreholes (Fig. 2, Maheshwaram area, Ranga Reddy District, Andhra Pradesh, India).

\section{Geological setting}

The studied sites are located $40 \mathrm{~km}$ south of Hyderabad (Andhra Pradesh, India). The area is characterized by a relatively flat topography with altitudes ranging from 670 to $590 \mathrm{~m}$ above mean sea level. The region experiences a semi-arid climate controlled by the periodicity of the monsoon (rainy season: June to October). Mean annual precipitation is about $750 \mathrm{~mm}$, of which more than $90 \%$ falls during the monsoon season.

The area is underlain by Archean biotite granite that is locally intruded by leucocratic granite. These granites are affected by deep in-situ multi-phase weathering-and-erosion processes (Dewandel et al., 2006). At the regional scale, the weathered horizons more or less follow the current topography and, from top to bottom, are composed of:

- A 1-3-m thick layer of sandy regolith, locally capped by a lateritic crust $(<50 \mathrm{~cm})$; - A 10-15-m thick layer of laminated saprolite;

- And, a 15-20-m thick layer of fissured granite, where weathered granite and clay minerals can partially fill the fissures.

The granites are locally intruded by up to 40-m-wide quartz veins (Archean in age) and metrewide dolerite dykes (2.5 to 1.6 Ga; G.S.I. 2002; Fig. 2). Quartz reefs systematically occupy positive relief in the area. In order to investigate the impact of such discontinuities on the 
131 weathering-profile structure and its hydrodynamic properties, geological and geophysical investigations were carried out on two pilot sites: "IFP 1" and "Kothur" (Figs. 2 and 3). The two sites, separated by $7 \mathrm{~km}$, are located along the same sub-vertical and north-south

134 decametre-wide quartz reef.

135 Electrical Resistivity Tomography profiles were carried out on the two sites for siting the 21 136 boreholes used in the study (Chandra et al., 2010). Five ERT profiles were carried on the 137 Kothur site and one on the IFP1 site. All ERT profiles show that the quartz reef, particularly 138 at depth, is characterized by lower resistivities than the surrounding granite, which is attributed to a more developed fissure network at depth (see supplemental material).At Kothur six boreholes were drilled in the central area and in the pinch-out zone of the quartz reef and 5

141 in the surrounding granite (Fig. 3a and 3b). The ten IFP1 boreholes were located within the 142 granite in the pinch-out zone of the quartz reef and near a metre-wide dolerite dyke (Fig. 3a) 143 that was intersected by two boreholes (IFP 1-4 and 1-8). The depth of the 21 boreholes ranges 144 between 35 and $91.4 \mathrm{~m}$ (Table 1); detailed geological logs were prepared from drill cuttings 145 (see supplemental material). At IFP1 site, two pre-existing farmer's wells (bw1 and bw2, 146 Fig. 3a) drilled within the granite are also present, but their exact depth is unknown.

147 The combination of the geophysical and the geological data allowed characterizing both the 148 structure of the geological formations and the geometry of the weathering profile near the 149 intrusion. Geological cross-sections perpendicular and parallel to the reef for the two sites 150 clearly show that the weathering profile is significantly deepened near the quartz reef (Figs $1514 \mathrm{a}, \mathrm{b}$ and $\mathrm{c}$ ). At the outcrop scale, the orientation of major fissures (metre to decametre wide) 152 in the quartz reef was measured (see supplemental material). The fissures are mostly sub153 vertical and organized in two main sub-orthogonal sets, one sub-parallel $\left(\mathrm{N} 00090^{\circ}\right)$ to the 154 quartz vein and the second sub-orthogonal $\left(\mathrm{N} 10090^{\circ}\right)$ to it. A few sub-horizontal fissures were also observed, but due to the relatively flatness of the outcrops their number is probably underestimated. Within the first ten metres from surface, the quartz is highly weathered and

157 densely fissured from centimetre to decametre scale. However, near the contact with the 158 granite, i.e. on the sides of the quartz reef and in the pinch-out zones, this highly weathered 159 and fissured material can reach up to $50 \mathrm{~m}$ depth (Figs. $4 \mathrm{~b}$ and c).Near the quartz reef, the 160 granite is also characterized by an important deepening of the weathering profile. On average, 161 saprolite thickness increases by a factor 1.5 to 3 and the fissured layer by a factor 3 to 5 , 162 compared to the zone not affected by the intrusion. Locally, the bottom of the fissured layer 163 can reach more than $70 \mathrm{~m}$ depth, whereas farther from the quartz reef the weathering profile 164 in the granite stops at few tens of metres from the surface (Figs. 4). 
The IFP1 sub-vertical and metre-wide dolerite dyke sub-parallel to the quartz reef is highly weathered within the first $6 \mathrm{~m}$ from the surface (clayey material), then poorly fissured up to $15 \mathrm{~m}$, and finally hard and compact. Near this dyke there is no-evidence of a deepening of the weathering front and of the development of a local deeper fissuring.

Previous studies (Maréchal et al., 2004; Dewandel et al., 2006) showed the relative homogeneity of the hydrodynamic properties of the weathered/fissured hard-rock aquifers where the granite is not affected by such discontinuities. Several questions now arise: are the hydrodynamic properties different in such verticalized weathered-fissured layers? Does the preferential orientation of fissures in the quartz reef play a role? What is the hydrogeological conceptual model of these discontinuities? To try and provide answers to these questions, slug tests and pumping tests were performed on both sites.

\section{Hydrodynamic investigations}

\subsection{Slug tests}

Twenty-one slug tests were carried out in the boreholes of both pilot sites and were interpreted using the Bouwer and Rice (1976) technique for unconfined aquifers with completely or partially penetrating wells. The obtained distribution of hydraulic conductivities constitutes a preliminary estimate of the hydraulic conductivity of the weathered layers in the granite and in the quartz aquifers near the wells (Fig. 5).

Near the quartz reef, the hydraulic conductivity of the fissured granite ranges from $8.5 \times 10^{-8}$ $\mathrm{m} / \mathrm{s}$ to $8.8 \times 10^{-6} \mathrm{~m} / \mathrm{s}$ with a geometrical mean of $2.4 \times 10^{-6} \mathrm{~m} / \mathrm{s}$ and a standard deviation of 0.6 computed on a logarithmic scale $\left(\log \mathrm{K}_{\text {slug: }}:-5.6 \pm 0.6\right)$. In the quartz reef, values are similar and range from $5.0 \times 10^{-8} \mathrm{~m} / \mathrm{s}$ up to $1.6 \times 10^{-5} \mathrm{~m} / \mathrm{s}$ with a geometrical mean of $2.6 \times 10^{-6} \mathrm{~m} / \mathrm{s}$ and a standard deviation on a $\log$ scale of $1.0\left(\log \mathrm{K}_{\text {slug }}:-5.6 \pm 1.0\right)$. Within these distributions, a small population of two boreholes (IFP30-3, K=8.5 x 10-8 $\mathrm{m} / \mathrm{s}$ and IFP30-6, K=5.1 x $10^{-8} \mathrm{~m} / \mathrm{s}$ ) with hydraulic conductivities of less than $10^{-7} \mathrm{~m} / \mathrm{s}$ corresponds to poorly fissured granite and quartz and is possibly representative of the matrix hydraulic conductivity. The hydrodynamic properties of the dolerite dyke were not explored since no water contribution was observed during drilling despite the shallow water-table (4 $\mathrm{m}$ from surface). The hydraulic conductivity distributions in the quartz reef and in the nearby granite seem to follow near-log normal distributions, similar to that of the stratiform fissured layer far from discontinuities in the same granite (geometric mean of $4.4 \times 10^{-6} \mathrm{~m} / \mathrm{s}$, Maréchal et al., 2004). However, the spatial distribution of hydraulic conductivity in the quartz reef is highly variable and is closely linked 
with the degree of weathering. Indeed, at the centre of the quartz reef, where a high grade of weathering and fissuring only affects the first metres below surface, the quartz is characterized by quite low hydraulic conductivities (IFP30-1, 30-6; K<5 x $10^{-7} \mathrm{~m} / \mathrm{s}$ ), whereas it is significantly more permeable near the contact with granite (e.g., IFP30-9, 30-10, 30-11; $\mathrm{K}>10^{-5} \mathrm{~m} / \mathrm{s}$ ). This shows that most of the conductive fissures develop in the contact zones (i.e. sides and pinch-out zones), whereas the heart of the reef is poorly fissured.

For the granite, no clear relationship between hydraulic conductivity and location relative to the quartz reef is found, suggesting that both near and far from the discontinuity the fissured layer of the granite exhibits similar properties.

\subsection{Pumping tests}

\subsubsection{Brief description of the method used}

The interpretation of pumping tests in such fissured aquifers commonly is a difficult task, as groundwater flow can be fractionalized (Black, 1994; Le Borgne et al., 2004) and controlled by the hydraulic conductivity of fissures, their density and orientation, and also their relationships with low-hydraulic-conductivity blocks or matrix (e.g. Maréchal et al., 2004; Le Borgne et al., 2006). In order to reveal the various aspects of the hydrodynamic properties of such a complex medium and to appropriately model the pumping test, a special attention has been paid to diagnosing of the tests prior to their modelling. Diagnoses were based on the analysis of derivative drawdown curves on log-log plots that allows flow-regime identification (Bourdet et al., 1983, 1989; Ehlig-Economides, 1988; Spane and Wurstner, 1993, Renard et al., 2009). The tests were then interpreted with WinISAPE (BRGM software) and WTFM (Lods and Gouze, 2004).Table2 presents the main characteristics of the pumping tests.

The observations and models were visually matched on both drawdown and derivative curves. The sensitivity of the hydrodynamic-parameter estimates was inferred from several fitting tests: it is less than $15 \%$ on average for the hydraulic conductivity and less than $20 \%$ on average for storativity. Since 34 curves were interpreted for the study, only a few curves are presented here (Fig. 6a, b and c).

\subsubsection{Pumping tests at the Kothur site}

Three non-simultaneous pumping tests were performed, two within the quartz reef (IFP30-5 and IFP30-10) and one within in the stratiform fissured layer of the granite (IFP30-4) at a quite large distance from the quartz vein (Fig. 3b; Tables 3 to 5). 
232 Pumping in IFP30-5 revealed spherical flow during the early stage of pumping (-1/2 slope of derivative curve; $\mathrm{t}<100 \mathrm{~min}$; Fig. 6a) that is typical of a borehole partially penetrating the aquifer. As this well intersects about 30 to $40 \mathrm{~m}$ of fractured quartz (Fig. 4c), this diagnosis suggests that IFP30-5 is located in a zone where the aquifer is relatively thin compared to where the drawdown progresses. This is corroborated by the geological observations, which show that the thickness of the weathered/fissured zone increases up to $70 \mathrm{~m}$ depth north of the site (Fig. 4c). The whole data set from pumping and observation wells has been interpreted with the Hantush model (partially penetrating aquifer with vertical anisotropy in hydraulic conductivity; Hantush, 1961; Fig. 6a). Estimated hydrodynamic parameters are of the same order of magnitude and relatively close from one well to the next with, however, a variability in the estimates and particularly those for hydraulic conductivity and storativity (Table 3); this point will be discussed later. On average, the hydraulic conductivity is $4.0 \times 10^{-6} \mathrm{~m} / \mathrm{s}$, the storativity about $3.2 \times 10^{-4}(-)$ and the aquifer thickness is estimated to be about $100 \mathrm{~m}$. The computed aquifer thickness appears slightly overestimated compared to reality (about $70 \mathrm{~m}$ ), which we explain by the uncertainty of the real productive length in wells (screened thickness on Table 3) but also by the use of the Hantush model that considers a well that partially penetrates the aquifer whereas IFP30-5 is located in a pinch-out zone of the aquifer. The vertical anisotropy ratio in hydraulic conductivity $(\mathrm{Kx} / \mathrm{Kz})$ is about 3 and probably reveals a depth-decreasing hydraulic conductivity due to a depth-decreasing density of fissures.

The test performed in IFP30-10 revealed a dual porosity behaviour (Fig. 6b). The overall data set has thus been interpreted with a dual porosity model. Two observation wells (IFP30-6 and 30-7) were interpreted in the matrix, the others being in the fissure network (Table 4; Fig. 6b). Compared to the previous pumping test, spherical flow is absent showing that IFP30-10 intersected most of the aquifer thickness and thus that the bottom of the aquifer is close to $70 \mathrm{~m}$ deep. The estimated hydrodynamic parameters are consistent with the ones obtained in IFP30-5 and of the same order of magnitude (Table 4). This test gives complementary information on the hydraulic parameters of the quartz reef aquifer. On average, the hydraulic conductivity of the aquifer is $6.2 \times 10^{-6} \mathrm{~m} / \mathrm{s}$, the storativity is about $4.6 \times 10^{-4}(80 \%$ in the matrix and $20 \%$ in the fissures), and the matrix hydraulic conductivity is about $2.4 \times 10^{-9} \mathrm{~m} / \mathrm{s}$. Variability in hydraulic conductivity and storativity estimates was also noted and will be discussed later.

The third test at Kothur (IFP30-4) characterises the stratiform fissured layer of the granite not affected by the reef. Only two observation wells reacted to the test (IFP30-7 and 30-8). The aquifer behaviour is typical of a dual-porosity medium and the hydrodynamic parameters are 
very similar (Table 5). The hydraulic conductivity of the fissured granite is on average $6.4 \mathrm{x}$ $10^{-6} \mathrm{~m} / \mathrm{s}$, the storativity is about $7.2 \times 10^{-3}$ (98\% in the matrix, $2 \%$ in the fissures), and the matrix hydraulic conductivity is about $3.0 \times 10^{-9} \mathrm{~m} / \mathrm{s}$.

\subsubsection{Pumping tests at the IFP1 site}

271 At the IFP1 site, wells were drilled in the granite, in the pinch-out zone of the quartz reef 272 (Fig. 3a). A pumping test in IFP1-6 revealed the channelized structure of the aquifer after a 273 few minutes of pumping (1/2 slope of the derivative curve on Fig. 6c). This is consistent with 274 the geological information and particularly the ' $U$ '-shape geometry of the aquifer (Fig. 4a). Therefore, a Theis model combined with two parallel no-flow boundaries was used for the interpretation (Fig. 6c). Several hypotheses were tested for the orientation of the two no-flow boundaries. The best result, which was constrained by the modelled drawdowns for the 10 wells, was obtained for a direction sub-parallel to the quartz reef (N195). Aquifer parameters are quite homogeneous (Table 6) with, however, a certain variability in the hydraulic conductivity and storativity values. The average hydraulic conductivity is $4.5 \times 10^{-6} \mathrm{~m} / \mathrm{s}$ and the average storativity $7.8 \times 10^{-4}(-)$. Distances from IFP1-6 to the two no-flow boundaries are on average 20 and $44 \mathrm{~m}$ respectively, which is consistent with the geological information (Fig. 4a). The nearest no-flow boundary, located east of IFP1-6 (d1=19.5 $\pm 9 \mathrm{~m})$, corresponds to the dolerite dyke while the farthest boundary is the western limit of the verticalized fissured layer of the granite $(\mathrm{d} 2=44.3 \pm 2 \mathrm{~m})$.

Nevertheless, some discrepancies to this overall interpretation are found. Interpretation of the observation well IFP1 data gives higher distances to limits, and particularly to the farthest one $(138 \mathrm{~m})$ because of the very low storage coefficient computed for this well $\left(\mathrm{S}=7 \times 10^{-5}\right.$; dist.limit=1.5[Tt/S $\left.]^{1 / 2} ; \mathrm{Jacob}, 1947\right)$. This low value compared to the average found for the site is probably caused by a highly conductive zone connecting this well to the pumping well thus enhancing a rapid pressure transfer between the two wells, quicker than the general one found at the site scale. The re-computation of the distance to limits with the average storage coefficient found at the site scale gives results that are consistent with the ones found in the other wells (Table 6). Compared to other wells, drawdown at IFP 1-3, 1-4 and 1-8 was very low $(<0.8 \mathrm{~m})$ which is explained by their location outside the permeable channel (Figs. 3a and 4a). The data were interpreted with the Theis model, but the estimated hydraulic parameters, $\mathrm{K}$ and $\mathrm{S}$, are non-realistic and differ by several orders of magnitude from the ones obtained in other wells. These wells are thus located in an aquifer that is poorly connected to the 
permeable channel. These records nevertheless show that the dolerite dyke no-flow boundary

300 is not a completely impervious limit, but rather a low-permeability barrier.

301 The second test performed in IFP1-8 produced drawdown in only a few observation wells (IFP1-4 and farmer wells BW1 and 2; Fig. 3a). The eight other observation wells did not react

303 to pumping, corroborating the presence of a no-flow boundary between IFP1-8 and IFP1-5,

304 i.e. the dolerite dyke. This test reinforces the scheme deduced from the test at IFP1-6. The

305 interpretations give similar results, with an average hydraulic conductivity of the aquifer at $3061.5 \times 10^{-5} \mathrm{~m} / \mathrm{s}$ and a storativity, $\mathrm{S}$, of about $2.2 \times 10^{-4}(-)$.

\subsection{Anisotropy and heterogeneity in hydraulic conductivity}

309 Fissure measurements on the quartz-reef outcrops at IFP1 and Kothur sites show that the

310 fissure network is well organized with dominant sets that are sub-parallel and sub-orthogonal

311 to the reef axis (see supplemental material). Moreover, the variability in hydraulic 312 conductivity - particularly within the quartz reef $\left(\log K_{\text {slug }}:-5.6 \pm 1.0\right)$ - is high because of the 313 variation in the weathering grade. As a consequence, anisotropy and heterogeneity in 314 hydraulic conductivity are expected and may explain the variability in hydraulic conductivity and storativity deduced from the pumping tests.

\subsubsection{Homogeneous and anisotropic aquifer: the stratiform horizontal fissured layer}

318 In an ideal homogeneous and anisotropic aquifer, the hydraulic conductivity on the horizontal 319 plane can be represented by a tensor characterized by two orthogonal major and minor axes.

320 When a pumping test is performed, the drawdown geometry forms an ellipse that reflects the anisotropy ratio (Hantush, 1966; Hantush and Thomas, 1966; Ramey, 1975; Neuman et al., 1984). The estimation of the anisotropy ratio and of the major and minor hydraulic conductivity orientations requires several observation wells located at various angle from the two anisotropy axes (e.g. Neuman et al., 1984). For such a medium and considering an isotropic storativity, drawdown curves from observation wells will all be characterized by the same semi-log slope (Jacob's straight-line), regardless of the distance to the pumping well, leading to equal estimated transmissivity or hydraulic conductivity values for each observation well. Only the intercept of the straight line with the time axis will differ because the anisotropy terms are only incorporated in the well-function (or within the log term for the Jacob's approximation). The analytical solutions used here start (Theis + two no-flow 331 boundaries) or end (Hantush and dual porosity) with radial flow (straight-line on semi-log 332 diagram), suggesting that in the scheme of an ideal anisotropic aquifer the hydraulic 
conductivity estimates for a particular pumping test should be the same or very close between wells. Such a statement is valid for the test performed at IFP30-4 in the horizontal stratiform fissured granite far from the quartz reef, where observation wells are laid out at right angles $\left(\mathrm{K} \_30-4 \approx \mathrm{K} \_30-8 \approx \mathrm{K} \_30-3 \approx 6.4 \times 10^{-6} \mathrm{~m} / \mathrm{s}\right.$; Table 5$)$. In addition, the estimated storativity for the two observation wells is very close $\left(7-8 \times 10^{-3}\right)$, indicating an anisotropy ratio near 1 when using the earlier mentioned anisotropic model. This suggests that at IFP30-4 the stratiform horizontal fissured layer is neither affected by a significant anisotropy in hydraulic conductivity onto the horizontal plane, nor affected by significant heterogeneities in hydraulic conductivity at the pumping-test scale. However, this information should be confirmed by one or more additional observation wells in other directions, or by additional tests in one of the two observation wells (Neuman et al., 1984).

\subsubsection{Heterogeneous and anisotropic aquifer: verticalized fissured granite and quartz} In the quartz reef (tests in IFP30-5 and IFP30-10) and in the granite at the pinch-out zone of the reef (IFP1-6), the estimated hydraulic conductivity differs between wells with a factor between 3 and 5 (Tables 3, 4 and 6). This implies that the tested aquifers are not ideal anisotropic aquifers or/and are affected by significant heterogeneity in hydraulic conductivity as illustrated by the analysis of slug-test data (Fig. 5).

Based on synthetic aquifers with heterogeneous transmissivity and homogeneous storativity, Meier et al. (1998) and Sánchez-Vila et al. (1999) showed that for long-duration tests the transmissivity values obtained with the Jacob straight-line method on observation wells at various distances from the pumping well are almost identical to the average transmissivity of the medium, even if the heterogeneity in transmissivity is important. However, storativity estimates vary considerably which, according to these works, is a result of the heterogeneity in transmissivity. Our aquifer hydraulic conductivity and storativity data set can be interpreted similarly: the used methods provide representative hydraulic conductivity values of the aquifers since $\mathrm{K}$ estimates are comparable, and the high variability in storativity estimates, which can be about an order of magnitude for the same test, may be the consequence of a heterogeneous hydraulic conductivity field. According to Meier et al. (1998) and SánchezVila et al. (1999), a well located in a high hydraulic-conductivity zone compared to the estimated one, results in an overestimated storativity value, and vice versa. Furthermore, the obtained transmissivity depends not only on the transmissivity values along the connecting path, but also on the average transmissivity values of the full domain (Sánchez-Vila et al., 1999). With our data set, no correlation between slug-test data and storativity was found, 
probably because of the very local estimation assigned to this method (slug tests have an action radius of a few metres around the well). Strong increases of the transmissivity variability of these numerical models, which was introduced by increases in the variance transmissivity fields, produced ellipsoidal shapes of estimated transmissivity around the pumping well, which were even better defined when the highest transmissivity zones were connected by highly permeable fractures. Even though these shapes may be exaggerated due to numerical artefacts, they seem nevertheless related to the transmissivity field. This point was, however, not discussed by the authors.

3.3.3. Proposed methodology for identifying the major and minor axes in hydraulic conductivity and results

378 In order to understand the variations in hydraulic conductivity estimated from one well to another, we prepared graphs representing the hydraulic conductivity values obtained at each observation well on the $\mathrm{X}-\mathrm{Y}$ plane ( $\mathrm{K}$ values from Tables 3, 4 and 6). If hydraulic conductivity estimates depend upon the hydraulic conductivity values along the connecting path between the pumping well and the observation well as well as on the average hydraulic conductivity value at the pumping test scale, one may expect variations in estimated values according to the direction between the pumping well and the observation well.

The hydraulic conductivity estimated in a particular observation well (Kobs.well) is plotted as a function of the angle $\beta$ between the geographical north (reference axis) and the pumpingwell / observation-well direction. Each Kobs.well is thus defined by two components, $K_{E}$ representing the projection onto the east-west or X-axis $\left(K_{E}=K o b s\right.$.wellx $\left.\operatorname{Cos} \beta\right)$ and $K_{N}$, the projection onto the north-south or Y-axis $\left(K_{N}=\right.$ Kobs.wellxSin $\left.\beta\right)$. The pumping well is located at the centre of the graph.

391 The three tests where the method was applied (Figs. 7a, b and c) clearly show correlations between the estimated hydraulic conductivity and the orientation of the well to the pumping well. Regardless of the distance between pumping well and observation well, the plotted 394 hydraulic conductivities describe ellipses showing that the hydraulic conductivities obtained along the reef axis are systematically larger than the orthogonal estimates. Higher values are explained by the velocity at which the drawdown propagates, which depends upon the hydraulic diffusivity ( $D=K . b / S ; b$ being the aquifer thickness). Because the variability in hydraulic conductivity is usually much larger than the storativity one, diffusivity is thus large for highly conductive zones and small for low-conductivity zones. Thus, when pumping, a 
vertical hydraulic gradient from lower to higher conductive zones is induced, which means that the highly conductive fissures or the fissure network that is best connected to the pumping well can be regarded as drainage structures or as lateral extensions of the well (Schad and Teutsch, 1994).

Hydraulic conductivity ellipses are defined by major and minor axes (Kmax and Kmin) and are supposed to characterize an average pseudo or apparent anisotropy introduced by the heterogeneity in hydraulic conductivity of the aquifer, or, in the case of fractured media, the variability in hydraulic connectivity with the different well locations; $\alpha$ representing the angle between the Y-axis and Kmax. The ratios Kmax/Kmin are comparable, between 2.6 and 3.1, and reveal the degree to which the fissures in the two orthogonal orientations are connected; however, the ratio values were not interpreted in a quantitative sense. To agree with previous work - the evaluated hydraulic conductivity at the pumping well should be representative of the whole heterogeneous medium (Meier et al., 1998) - but also to validate the analysis, the hydraulic conductivity estimated for the pumping well should represent the average hydraulic conductivity of the aquifer and should be close to the average hydraulic conductivity value deduced from this analysis $\left(K_{\text {mean }}=[\operatorname{Kmax} . K \min ]^{0.5}\right)$. Using such an approach, $K_{\text {mean } \_30-10}=5.9$ $\mathrm{x} 10^{-6} \mathrm{~m} / \mathrm{s}$ is compared to $\mathrm{K}_{\mathrm{IFP} 30-10}=6.3 \times 10^{-6} \mathrm{~m} / \mathrm{s}, K_{\text {mean } \_30-5}=3.6 \times 10^{-6} \mathrm{~m} / \mathrm{s}$ to $\mathrm{K}_{\mathrm{IFP} 30-5}=4.2 \mathrm{x}$ $10^{-6} \mathrm{~m} / \mathrm{s}$, and $K_{\text {mean_l- } 6}=5.1 \times 10^{-6} \mathrm{~m} / \mathrm{s}$ to $\mathrm{K}_{\text {IFP1-6 }}=5.1 \times 10^{-6} \mathrm{~m} / \mathrm{s}$. Differences are thus small, between 0 to $15 \%$, compared to the ones obtained from pumping wells. However, the ellipses are mismatched in a few points. Some lie outside the ellipse, such as IFP1-1, which suggests that the pressure transfer is easier between this well and the pumping well due to a preferential flow path as previously suggested, or they lie inside the ellipse due to a lower conductive zone (IFP30-8, IF30-7; Fig. 7b).

From this analysis, it results that the major ellipse axes are clearly oriented sub-parallel to the quartz reef. Consequently, for the tests in the quartz reef, it can be concluded that the subvertical fissure set parallel to the reef axis ensures a preferential connection between the pumped and the other wells. However, at right angles to the reef the connection is lower, most probably because of the variation in the degree of fissuring between the heart and the side of the reef.

In the verticalized fissured layer at the quartz vein pinch-out zone (Fig. 7c), we also find variability in the connectivity of the fissure network. The major axis is also sub-parallel to the sub-vertical fissure set and parallel to the reef axis. This result suggests that in the pinch-out zone of the quartz reef, and probably also at the contacts on the eastern and western sides, the verticalized fissured granite is affected by a dominant set of sub-vertical conductive fissures 
sub-parallel to the reef. This feature differs from the classic stratiform horizontal fissured layer, where horizontal conductive fissures dominate (Fig. 1; Maréchal et al., 2004).

\section{HYDROGEOLOGICAL CONCEPTUAL MODEL OF THE QUARTZ REEF}

Geological, hydrogeological and geophysical investigations performed along the quartz reef allow completing the understanding of the structure and the hydrogeological properties of hard-rock aquifers exposed to deep weathering processes (Fig. 8).

\subsection{Aquifer geometry}

Near the quartz reef the weathering fronts within the granite (e.g. bottom of saprolite and of the fissured layer) are noticeably deeper compared to the classic stratiform weathering profile. On average, the thickness of the saprolite increases by a factor of 1.5 to 3 and that of the fissured layer by a factor of 3 to 5 . Near the contact, the geometry of the weathering profile in the granite is, as for the classic stratiform weathering profile, characterized by two subparallel layers: the saprolite and the fissured layers. However, they are not sub-parallel to the paleo-surface contemporaneous with the weathering, but sub-parallel to the discontinuity borders. As a result, the weathering profile exhibits a ' $U$ ' shape composed of parallel layers. The quartz reef is characterized by mainly sub-vertical fissures that are sub-parallel and suborthogonal to the reef axis. The top layer is highly fissured and weathered and the fissure density rapidly decreases with depth. Density in fissuring and the grade of weathering vary also in space and are more pronounced at the contact with granite, i.e. on the sides and in the pinch-out zones, than at the heart of the vein. This ' $U$ ' shape of the weathering layers results from similar processes as those observed in horizontal stratiform weathering profiles:

(i) The constraints resulting from the development of the weathering profile in the granite surrounding the quartz reef induce fissuring of the quartz reef. This explains the numerous metre- to decametre-wide fissures observed in the quartz reef outcrops. Constraints in the granite are induced by the swelling of some minerals, particularly biotite (Wyns et al., 1999, 2004; Lachassagne et al., 2011);

(ii) This weathering-induced fissuring enhances water circulation and in return favours a local deepening of the weathering fronts in the granite near the contact with the quartz reef. The lower strain is thus deviated in the direction of the discontinuity, which favours 
the development of a verticalized fissured layer in the granite at the contact with the reef. This point is supported by the heterogeneity in hydraulic conductivity, which shows evidence that this layer is characterized by dominant conductive fissures sub-parallel to the intrusion

(iii) The induced weathering favours deeper fissures in the quartz vein, and so on.

Thus, during the weathering of granitic formations such a discontinuity favours a local deepening of the weathering fronts in the host rock and thus favours a thickening of the transmissive part of the aquifer (the fissured layer). In addition, the quartz vein is also subject to weathering. It causes small-scale fissures that further enhance the hydraulic conductivity. This in situ weathering amplifies the above-described process.

Intrusives or veins whose weathering products are of low permeability, such as those of dolerite dykes, do not favour water circulation, neither in their heart, nor around them. The stratiform weathering profile of the neighbouring granite thus remains undisturbed. Moreover, such dykes —as in the case of the IFP1 site- act as low-permeability barriers that compartment the horizontal fissured layer.

\subsection{Hydrodynamic properties of the aquifer}

\subsubsection{Granite near the contact with the discontinuity}

Far from the quartz reef, the stratiform horizontal fissured layer of the granite is characterized by quite homogenous hydrodynamic parameters (pumping tests in IFP1-8 and IFP30-4): the hydraulic conductivity is about $10^{-5} \mathrm{~m} / \mathrm{s}$ and the storativity ranges between 0.2 and $7 \times 10^{-3}$. These values are similar to the ones found in the same area: $K=5 \times 10^{-5} \mathrm{~m} / \mathrm{s}$ and $\mathrm{S}=6 \times 10^{-3}$, (Maréchal et al., 2004), and $\mathrm{K}=1.6 \times 10^{-5} \mathrm{~m} / \mathrm{s}$ (Dewandel et al., 2006). As previously shown by Maréchal et al. (2004), the granite is characterized by dual-porosity behaviour, being affected by sub-horizontal and sub-vertical fissure networks and low-permeability blocks with a hydraulic conductivity of about $3 \times 10^{-9} \mathrm{~m} / \mathrm{s}$. In addition, the two fissure sets induce a significant horizontal anisotropy in permeability $\left(\mathrm{K}_{\text {horiz. }} / \mathrm{K}_{\mathrm{vert}}: 10\right)$ because of the welldeveloped horizontal conductive fissure network. The pumping test performed in IFP1-8 within the horizontal fissured layer did not show such behaviour as a result of the presence of the low-permeability dolerite dyke which became apparent at the early stage of the pumping and masked the dual-porosity behaviour.

The average hydraulic conductivity of the verticalized fissured layer along the quartz reef is about $4.5 \times 10^{-6} \mathrm{~m} / \mathrm{s}$, and the average storage coefficient $7.8 \times 10^{-4}(-)$. The similarity between these values and the ones from the 'classic' stratiform horizontal fissured layer in the area 
suggests that the conductive zones of both horizontal and verticalized fissured layers have a 502 similar origin, i.e. weathering processes. As in the case of the IFP1-8 test, the two no-flowboundaries that appear at the early stage of pumping in IFP1-6 probably masked the dualporosity behaviour of the verticalized granite. However, this layer may also behave like such a medium, as suggested by the low local hydraulic-conductivity values derived from slug tests, 1 to $4 \times 10^{-7} \mathrm{~m} / \mathrm{s}$ (IFP30-3 and IFP1-3), which are typical of the hydraulic conductivity values in the block as given by Maréchal et al. (2004). Thus, the verticalized fissured layer of the granite along the contact with the reef is formed by a conductive fissure network $\left(4.5 \times 10^{-}\right.$ ${ }^{6} \mathrm{~m} / \mathrm{s}$ ) and possibly by low-permeability blocks (about $10^{-7} \mathrm{~m} / \mathrm{s}$ ). In addition, this verticalized layer is characterized by a dominant set of conductive fissures that are sub-vertical and subparallel to the reef axis $(\mathrm{Ky}>\mathrm{Kx})$. This result differs from the 'classic' horizontal fissured layer, where no significant anisotropy was found in the horizontal plane ( $\mathrm{Kx} \approx \mathrm{Ky}$ at IFP30-4) and where a conductive sub-horizontal fissure network dominates $\left(\mathrm{K}_{\mathrm{x}} / \mathrm{K}_{\mathrm{z}}=10\right.$; Maréchal et al., 2004).

\subsubsection{Quartz aquifer}

The fissured quartz is characterized by a dual-porosity behaviour; the average hydraulic conductivity of the fissure network is 4 to $6 \times 10^{-6} \mathrm{~m} / \mathrm{s}$, storativity being 3 to $5 \times 10^{-4}$ and mainly ensured by low-permeability blocks $\left(2.4 \times 10^{-9} \mathrm{~m} / \mathrm{s}\right)$. However, hydrodynamic properties in the quartz are highly variable in space and closely depend upon the grade of weathering and fissuring: it is poorly fissured with low permeability in the heart and highly conductive at the contact with granite due to an enhanced fissuring. The fissured quartz is also characterized by anisotropy onto the vertical plane, $\mathrm{K}_{\mathrm{x}} / \mathrm{K}_{\mathrm{z}}: 3$, which is attributed to a decreasing density with depth of the conductive fissures. As for the verticalized fissured layer of the granite, conductive fissures that are sub-vertical and sub-parallel to the reef dominate in the quartz, inducing a higher hydraulic conductivity parallel to the reef $(\mathrm{Ky}>\mathrm{Kx})$; however, the anisotropy in hydraulic conductivity could not be estimated.

528 Even if at Kothur site the aquifer also has a ' $U$ ' shape, hydraulic tests do not show evidence of channelized groundwater flow. This is explained by the fact that during the tests the groundwater level was very shallow (4 to $5 \mathrm{~m}$ deep) whereas it was more than $15 \mathrm{~m}$ deep at the IFP1 site. As a consequence, at Kothur the 'U'-shape aquifer was still well-connected to the surrounding horizontal stratiform fissured layer of the granite aquifer, giving the impression of an infinite aquifer while at the IFP1 site only the ' $U$ ' shape aquifer contributed to pumping. 


\section{CONCLUSIONS}

537 The obtained results complement the conceptual hydrogeological model developed for granite

538 aquifers (Taylor and Howard, 2000; Maréchal et al., 2004; Dewandel et al., 2006) in places

539 where geological discontinuities disturb the weathering profile.

540 Near the quartz reef, weathering processes appear to be at the origin of an enhanced local

541 hydraulic conductivity both in the vein and in the surrounding granite. The quartz reef and the

542 accompanying verticalized fissured granite layer at the contact constitute a composite aquifer

543 characterized by a ' $U$ '-shaped geometry that acts as a local drain. This higher permeability is

544 probably at the origin of the sharp deepening of the weathering front in the surrounding

545 granite and in the quartz reef itself. Hydrodynamic properties of the verticalized fissured

546 granite are comparable to those found in the classic horizontal fissured layer. However, the

547 anisotropy in hydraulic conductivity is reversed as sub-vertical fissures control the

548 groundwater flow at the discontinuity, while fluxes in the classic horizontal fissured layer are

549 mostly controlled by a dominant set of sub-horizontal fissures.

550 Where the weathering can propagate downward, other geological discontinuities such as deep

551 fractures, leucocratic dykes, pegmatite, or contacts between different geological formations,

552 may also constitute local structures with similar aquifer properties as those described here. As

553 a result, the weathering front should also form a ' $U$ ' shape depending upon how vertical the

554 discontinuity is and on the duration of the weathering processes. Such types of structures,

555 searched for and observed by hydrogeologists and geophysicists for borehole siting (e.g.

556 Sander, 2007) are commonly attributed to "tectonic fracturing" ("fault gouges"). The novelty

557 here is to show that the geometry of the aquifer and its hydrodynamic properties are inherited

558 from deep and local in situ weathering processes, but are unrelated to tectonic activity.

559 Therefore, where this deepening of the weathering front has developed such structures may be

560 valuable targets for borehole siting, particularly because of the enhanced transmissivity due to

561 an increase in aquifer thickness. However, the permeability of such structures is highly

562 variable in space, being low in the heart and high at the contacts. Such contrasting

563 hydrodynamic properties, and also the more or less important development of the weathering

564 profile along these structures, may explain the high variability of well yields using a standard

565 approach based only on the study of lineaments. Thus, lineament studies combined with

566 structural studies of the weathering profile would improve the chances of siting productive

567 wells. At the opposite, discontinuities that produce weathering material of low permeability, 
such as dolerite dykes, do not locally enhance the thickness of weathered layers in granite or its hydraulic conductivity, making such structures unfavourable targets.

Numerical issues, both for modelling the evolution of the weathering profile along such discontinuities and for modelling of the tests, as well as additional hydraulic tests to assess preferential flow paths (flowmeter tests), to pursue the quantification of heterogeneity in hydrodynamic properties in relation to underground reality (fissures orientation, structure of the weathered layers), are topics of interest for future research. In addition, the development of new analytical solutions for the interpretation of pumping tests in such media would help in improving their characterization, such as including anisotropy, channelized flow and/or the influence of surrounding aquifers.

Finally, because of the complex structures and associated properties of such aquifers, special attention has to be paid to water management. The channelized or fractionalized patterns of the flow paths have strong implications in terms of contaminant transport and for delineating appropriate protection perimeters for water-supply wells. Efforts should thus be made for improving the hydrogeological and hydrogeochemical characterization of these aquifers to ensure their safe and sustainable groundwater exploitation. The methods for characterizing the aquifer used here could be used and improved for achieving this goal.

\section{Acknowledgements}

The authors are grateful to the research-sponsorship from BRGM (France), the Embassy of France in India, ,NGRI (India) and from the French National Research Agency (ANR) under the VMCS2008 program (SHIVA project $n^{\circ}$ ANR-08-VULN-010-01). Colleagues from NGRI and BRGM are thanked for their fruitful comments, discussions and technical assistance in the field. The three anonymous Journal referees are thanked for their useful remarks and comments that improved the quality of the paper. We are grateful to Dr. H.M. Kluijver for revising the English text. 


\section{References}

596

597

598

599

600

601

602

603

604

605

606

607

608

609

610

611

612

613

614

615

616

617

618

619

620

621

622

623

624

625

626

627

Ayraud, V., Aquilina, L., ; Labasque, T., Pauwels, H., Molenat, J., Pierson-Wickmann, A.C., Durand, V., Bour, O., Tarits, C., Le Corre, P., Fourre, E., Merot, Pj. and Ph. Davy, 2008. Compartmentalization of physical and chemical properties in hard-rock aquifers deduced from chemical and groundwater age analyses. Applied Geochemistry, 2008, vol. 23 (9), 2686-2707.

Black, J.H. 1994. Hydrogeology of fractured rocks - a question of uncertainty about geometry, Applied Hydrogeology, 3, 56-70.

Blomqvist, R.G. 1990. Deep groundwater in the cristalline basement in Finland, with implications for waste disposal studies. Geologiska Foereningen $i$ Stockholm Foerhandlingar, vol.112(4), pp.369-374.

Bourdet, D., Whittle T.M., Dougals, A.A. and Y.M. Pirard. 1983. A new set of type curves simplifies well test analysis, World Oil.

Bourdet D., Ayoud J.A. and Y.M. Pirard. 1989. Use of pressure derivative in well-test interpretation. SPE, 293-302.

Bouwer, H. and Rice R.C. 1976. A slug test for determining hydraulic conductivity of unconfined aquifers with completely or partially penetrating wells. Water Resources Research, 12, 3, 423-428.

Chandra, S., Rao, V.A., Krishnamurthy, N.S., Dutta S., and Ahmed, S., 2006. Integrated studies for characterization of lineaments to locate groundwater potential zones in hard rock region of Karnataka, India. Hydrogeology Journal, 14(5), 767-776.

Chandra S., Dewandel B., Kumar D., Dutta S. Bhat A.N., Murthy N.S.K. and S. Ahmed. 2010. Geophysical Characterization of Quartz Reef Intrusive Lineaments in Granite Hard Rock for Groundwater Occurrences, Applied Geophysics, in press.

Chilton, P.J., and Foster, S.S.D. 1995. Hydrogeological characterization and water-supply potential of basement aquifers in tropical Africa. Hydrogeology J., 3(1), 36-49.

Chilton, P.J. and Smith-Carrington, A.K. 1984. Characteristics of the weathered basement aquifer in Malawi in relation to rural water supplies. Challenges in African Hydrology and Water Resources, proc. Harare Symposium, July 1984, pp.57-72.

Cho M., K-M. Ha, Y-S. Choi, W-S. Kee, P. Lachassagne and R. Wyns. 2003. Relationship between the permeability of hard-rock aquifers and their weathered cover based on geological and hydrogeological observation in South Korea. IAH Conference on "Groundwater in fractured rocks", Prague 15-19 September 2003, Prague. 
Courtois, N., Lachassagne, P., Wyns, R., Blanchin, R., Bougaïré, F.D., Somé, S. and A. Tapsoba. 2010. Country-scale hydrogeological mapping of hard-rock aquifers and its application to Burkina Faso, Ground Water, in press.

Dewandel B., Lachassagne P., R.Wyns, Maréchal J.C. and N.S. Krishnamurthy, 2006. A generalized hydrogeological conceptual model of granite aquifers controlled by single or multiphase weathering. Journal of Hydrology, 330, 260-284, doi:10.1016/j.jhydrol.2006.03.026.

Dewandel, B., Perrin, J., Ahmed, S., Aulong. S., Hrkal, Z., Lachassagne, P., Samad, M., S. Massuel. and A. Mukherji. 2008. Management of the groundwater resources in semiarid hard rock regions under variable water demand and climatic conditions: development of a Decision Support Tool. Groundwater \& Climate in Africa International Conference, Kampala, Uganda June 24-28.

Dewandel, B., Perrin, J., Ahmed, S., Aulong. S., Hrkal, Z., Lachassagne, P., Samad, M. and S. Massuel. 2010. Development of a Tool for managing groundwater resources in semi-arid hard rock regions. Application to a rural watershed in South India. Hydrological Processes, in press.

Ehlig-Economides, C.A. 1988. Use of the Pressure Derivative for Diagnosing PressureTransient Behavior, Journ. of Petroleum Technology, oct.1988.

G.I.S., 2002. Geological Survey of India. Geological map: Hyderabad quadrangle - Andhra Pradesh.

Gustafson, G. and J. Krásný. 1994. Crystalline rock aquifers: their occurrence, use and importance, Applied Hydrogeology, 2, 64-75.

Hantush, M.S. 1961. Aquifer tests on partially penetrating wells. Proc. of the Am. Soc. of Civil Engineers, 87, 171-195.

Hantush M.S. 1966. Analysis of data from pumping tests in anisotropic aquifers. J. Geophys. Res., 72, 1709-1720.

Hantush M.S. and R.G. Thomas. 1966. A method for analyzing a drawdown test in anisotropic aquifer. Trans. Am. Geophys. Union, 36, 281-285.

Houston, J.F.T., and R.T. Lewis. 1988. The Victoria Province drought relief project, II. Borehole yield relationships. Ground Water, 26(4), 418-426. 
Howard, K.W.F., M. Hughes, D.L. Charlesworth, and G. Ngobi. 1992. Hydrogeologic evaluation of fracture permeability in crystalline basement aquifers of Uganda. Applied Hydrogeology, 1, 55-65.

Jacob, C.E., 1947. Drawdown test to determine effective radius of an artesian well, ASCE Trans., 112(232), 1047-1064.

Krásný J. and J. Sharp, 2007. Hydrogeology of fractured rocks from particular fractures to regional approaches : state-of-the-art and future challenge. In: Krásný J. - Sharp J.M. (eds.): Groundwater in fractured rocks, IAH Selected Papers, 9, 1-30. Taylor and Francis.

Kuusela-Lahtinen, A., Niemi, A. and Luukkonen, A. 2003. Flow dimension as an indicator of hydraulic behaviour in site characterization of fractured rock. Ground Water, vol. 41 (3), pp.33-341.

Lachassagne, P., B. Dewandel B., R. Wyns. 2011. The fracture permeability of Hard Rock Aquifers is due neither to tectonics, nor to unloading, but to weathering processes. Terra Nova, 23, 145-161.

Lachassagne, P., R. Wyns, P. Bérard, T. Bruel, L. Chéry, T. Coutand, J.F. Desprats, and P. Le Strat. 2001. Exploitation of high-yield in hard-rock aquifers: Downscaling methodology combining GIS and multicriteria analysis to delineate field prospecting zones. Ground Water, 39(4), 568-581.

Le Borgne, Bour, O., de Dreuzy J.R., Davy, P. and F. Touchard. 2004. Equivalent mean flow models for fractured aquifers: insights from a pumping tests scaling interpretation. Water Res. Research, 40, W03512, 1-12.

Le Borgne, Bour, O., Paillet F.L and J-P. Caudal. 2006. Assessment of preferential flow path connectivity and hydraulic properties at single-borehole and cross-borehole scales in fractured aquifer. J. of Hydrology, 328, 347-359.

Leveinen, J., E. Rönkä, J. Tikkanen and E. Karro. 1998. Fractional flow dimensions and hydraulic properties of a fracture-zone aquifer, Leppävirta, Finland. Hydrogeology J., vol.6, 327-340.

Lods, G. and Ph. Gouze. 2004. WTFM, software for Well Test analysis in Fractured Media combining fractional flow with double porosity and leakance approaches. Computer \& Geosciences Journal. 937-947. 
Loke M.H., Barker R.D., 1996. Rapid least-squares inversion of apparent resistivity pseudosections using a quasi-Newton method. Geophysical Prospecting, 44, 131-152.

Mabee, S.B., Hardcastle, K.C. and Wise, D.U., 1994. A method of collecting and analyzing lineaments for regional scale fissured-bedrock aquifer studies. Ground Water, 32(4), pp.884-894.

Maréchal J.C., B. Dewandel, and K. Subrahmanyam. 2004. Use of hydraulic tests at different scales to characterize fracture network properties in the weathered-fissured layer of a hard rock aquifers. Water Resources Res., vol.40, W11508.

Maréchal, J.C., B. Dewandel, S. Ahmed, L. Galeazzi, 2006. Combining the groundwater budget and water table fluctuation methods to estimate specific yield and natural recharge. Journal of Hydrology, 329, 1-2, 281-293, doi:10.1016/j.jhydrol.2006.02.022.

Maréchal, J-C., Dewandel, B., Ahmed S. and P. Lachassagne, 2007. Hard-rock aquifers characterization prior to modelling at catchment scale: an application to India. In: Krásný J. - Sharp J.M. (eds.): Groundwater in fractured rocks, IAH Selected Papers, 9, 1-30. Taylor and Francis.

Meier, P.M., Carrera, J., and X. Sánchez-Vila, 1998. An evaluation of Jacob's method for the interpretation of pumping tests in heterogeneous formations. Water Resources Research, 34 (5), 1011-1025.

Nahon, D. B. 1991. Introduction to the Petrology of Soils and Chemical Weathering. Ed. Wiley.

Neuman, S.P., Walter G.R., Bentley H.W., Ward J.J. and D.D. Gonzalez. 1984. Determination of horizontal aquifer anisotropy with three wells. Ground Water, 22-1, 66-72.

Omorinbola, E.O. 1982. Verification of some geomorphological implcations of deep weathering in the basement complex of Nigeria. Journal of Hydrology, 56, 347-368.

Owoade, A. 1995. The potential for minimizing drawdowns in groundwater wells in tropical aquifers. Journ. of African Earth Sciences, 20, 3-4, 289-293.

Pickens, J.F., Grisak, G.E., Avis, J.D., Belanger, D.W. and Thury, M. 1987. Analysis and interpretation of borehole hydraulic tests in deep boreholes; principles model development, and applications. Water Resources Res., vol. 23(7), pp.1341-1375.

Ramey, H.J. 1975. Interference analysis for anisotropic formations - a case history. Jour. of Petroleum Technology., 1290-1298. 
Renard, Ph., Glenz D. and M. Mejias. 2009. Understanding diagnostic plots for well-test interpretation. Hydrogeology Journal, 17, 589-600.

Sánchez-Vila, X., Meier, P.M. and J. Carrera, 1999. Pumping tests in heterogeneous aquifers: an analytical study of what can be obtained from their interpretation using Jacob's method. Water Resources Research. 35 (4), 943-952.

Sander P, Minor TB, Chesley M.M. 1997. Groundwater exploration based on lineament analysis and reproducibility tests. Ground Water 35(5):888-894.

Sander P. 2007. Lineaments in groundwater exploration: a review of applications and limitations.- Hydrogeology Journal, 15(1), 71-74.

Schad, H. and G. Teutsch, 1994. Effects of the investigation scale on pumping test results in heterogeneous porous aquifers. Journal of Hydrology, 159, 61-77.

Spane F.A. and Wurstner S.K., 1993. DERIV: a computer program for calculating pressures derivatives fir use in hydraulic test analysis. Ground Water 31:814-822.

Tardy, Y., 1971. Characterization of the principal weathering types by the geochemistry of waters from some European and African crystalline massifs. Chemical Geology, vol.7, 253-271.

Tardy, Y. 1993. Pétrologie des latérites et des sols tropicaux.- 459 pp.- Masson, Paris.

Tardy, Y. 1998. Dérive des continents, latérites et paléoclimats tropicaux.- 472 pp.Editions BRGM, Orléans.

Taylor, R., and K. Howard. 2000. A tectono-geomorphic model of the hydrogeology of deeply weathered crystalline rock: evidence from Uganda. Hydrogeology J., 8(3), 279294.

Uhl, V.W. and G.K. Sharma. 1978. Results of pumping tests in crystalline-rock aquifers. Ground Water, vol.16 (3), pp. 192-203.

Walker, D.D., Gylling, B., Strom, A. and J.O. Selroos. 2001. Hydrogeologic studies for nuclear-waste disposal in Sweden. Hydrogeology J., vol.9(5), pp.419-431.

Wyns, R., J.-C. Gourry, J.-M. Baltassat, and F. Lebert. 1999. Caractérisation multiparamètres des horizons de subsurface (0-100 m) en contexte de socle altéré, in 2ème Colloque GEOFCAN, edited by BRGM, IRD, UPMC, pp. 105-110, Orléans, France. 
751 Wyns, R., J. M. Baltassat, P. Lachassagne, A. Legchenko, J. Vairon, and F. Mathieu. 2004. Application of SNMR soundings for groundwater reserves mapping in weathered basement rocks (Brittany, France), Bulletin de la Société Géologique de France, 175

754 (1), pp. 21-34. 


\section{Figure captions}

Figure 1. Idealized weathering profile in hard-rock intersected by the current topography. The insert presents the area of interest of the paper: geological discontinuities (Wyns et al., 1999).

Figure 2. Location of the studied area with main geological features (G.S.I., 2002);

Maheshwaram area, Ranga Reddy District, Andhra Pradesh, India.

763

Figure 3. Geological information and borehole locations. (a) IFP1 and (b) Kothur pilot sites.

765

766 Lines A, B and C materialize the cross sections (see Figs. 6), and the other dotted lines the location of electrical-resistivity profiles (identical to line A for IFP1 site). Grey curves: soil elevation (masl). BW: farmer's wells.

Figure 4. Interpreted geological cross sections. (a) perpendicular to the quartz reef at IFP1 site, (b) perpendicular and (c) parallel to the quartz reef at Kothur site. Location of the cross sections is shown on Figure 3 (lines A, B and C).

Figure 5. Histogram on a logarithmic scale of the hydraulic conductivity deduced from slug tests analysis. The data from the boreholes located in the quartz reef (average: LogK: -5.58 \pm 1.0 ; number of data [n]: 6) and in the granite surrounding the reef (average: LogK: -5.62 $\pm 0.6 ; \mathrm{n}: 15$ ) are compared to the granite far from discontinuities (average: LogK: $-5.36 \pm 1.0$, n: 30; Maheshwaram area [same area] Maréchal et al., 2004). LogK: natural logarithm of hydraulic conductivity.

Figure 6. Observed and modelled drawdowns and derivatives. (a) Pumping well IFP30-5 and observation well IFP30-2; model: Hantush (WinIsape software). (b) Pumping well IFP30-10, and observation wells IFP30-5 and IFP30-.6; model: dual porosity. IFP 30-6 considers the response of the matrix (WTFM software) (c) Pumping well IFP1-6 and observation well IFP1-9; model: Theis+2 no-flow boundaries (WinIsape software).

Figure 7. Heterogeneity in hydraulic conductivity on the horizontal plane. (a) Pumping at IFP30-5; hydraulic conductivity from Table 3. (b) Pumping at IFP30-10; hydraulic conductivity from Table 4. (c) Pumping at IFP1-6; hydraulic conductivity from Table 6. 
789 Circles: wells located in the quartz reef; triangles: wells located in the granite. Error bars

790 depict the range of the estimates deduced from the drawdown curve interpretations. $\alpha$. angle

791 between Ky and Kmax.

792

793 Figure 8. Idealized conceptual hydrodynamic model of the aquifer associated to the quartz

794 reef. Data from the horizontal stratiform fissured layer are from Maréchal et al. (2004) and

795 Dewandel et al. (2006).

\section{Table captions}

799

800 Table 1. Characteristics of the wells in the IFP1 and Kothur sites and hydraulic conductivity

$801 \quad(\mathrm{~K})$ deduced from slug tests.

802

803 Table 2. Characteristics of pumping tests performed at the IFP1 and Kothur pilot sites.

$804 *$ Geology of the aquifer zone; $* *$ drawdown at the end of pumping, and *** number of

805 observation wells that reacted to pumping. The diagnoses are deduced from derivative curve 806 analyses.

807

808 Table 3. Results of the interpretation of the pumping in IFP30-5 (Kothur site; quartz aquifer).

809 Model: Hantush (partially penetrating well). * drawdown at the end of pumping, ** $\mathrm{K}$ and $\mathrm{S}$

810 are geometrical mean; others are arithmetic mean, and *** estimated from geological logs.

811 StDev.: standard deviation.

812

813 Table 4. Results of the interpretation of pumping in IFP30-10 (Kothur site; quartz aquifer).

814 Model: dual-porosity. * observation well interpreted in the matrix, ** drawdown at the end of 815 pumping, and $* * *$ geometrical mean.

816

817 Table 5. Results of the interpretation of the pumping in IFP30-4 (Kothur site; granite aquifer).

818 Model: dual-porosity. * drawdown at the end of pumping, and ** geometrical mean.

820 Table 6. Results of the interpretations of pumping in IFP1-6 (IFP1 site; granite aquifer).

821 Model: Theis + two no-flow boundaries. * drawdown at the end of pumping, ** estimated 
822 using the average $\mathrm{S}(7.8 \mathrm{E}-4)$, *** the number between comas is estimated using the average $\mathrm{S}$

823 and $* * * * \mathrm{~K}$ and $\mathrm{S}$ are geometrical mean, do not include data from observation wells IFP 1-3,

$824 \quad 1-4$ and 1-8 (located in another aquifer); distances to limits are arithmetic mean.

825

826 


\begin{tabular}{|c|c|c|c|c|c|c|c|c|}
\hline Well ID & site & Depth $(\mathrm{m})$ & $\begin{array}{l}\text { Casing } \\
\text { depth } \\
(\mathrm{m})\end{array}$ & Main Geology & $\begin{array}{c}\text { Saprolite } \\
\text { thickness -granite } \\
(\mathrm{m})\end{array}$ & $\begin{array}{c}\text { Highly } \\
\text { weathered } \\
\text { quartz }(\mathrm{m})\end{array}$ & $\begin{array}{l}\text { Basement } \\
\text { depth }(m)\end{array}$ & $\underset{(\mathrm{m} / \mathrm{s})}{\text { K_slug }}$ \\
\hline IFP1 & IFP1 & 42.0 & 8.8 & Granite & 18.3 & - & 37.5 & 7.4E-06 \\
\hline IFP1-1 & IFP1 & 59.5 & 5.8 & Granite & 15.5 & - & 51 & $3.2 \mathrm{E}-06$ \\
\hline IFP1-2 & IFP1 & 35.0 & 12 & Granite & 22.5 & - & 30.2 & 7.4E-06 \\
\hline IFP1-3 & IFP1 & 35.0 & 5.7 & Granite & 17 & - & 29 & 4.4E-07 \\
\hline IFP1-4 & IFP1 & 68.6 & 6 & Dolerite+granite & no data & - & 77.7 & 7.6E-07 \\
\hline IFP1-5 & IFP1 & 73.2 & 11.6 & Granite & & 9 & 32 & $2.9 \mathrm{E}-06$ \\
\hline IFP1-6 & IFP1 & 73.2 & 22.9 & Granite & 13.5 & \begin{tabular}{|l|}
2.5 (overlying \\
the saprolite) \\
\end{tabular} & 51 & $3.1 \mathrm{E}-06$ \\
\hline IFP1-7 & IFP1 & 59.4 & 27.1 & Granite & 11.5 & & 44 & $3.9 \mathrm{E}-06$ \\
\hline IFP1-8 & IFP1 & 54.9 & 11.6 & Dolerite+granite & $\begin{array}{l}7 \mathrm{~m} \text { of highly } \\
\text { weathered } \\
\text { dolerite (clay) }\end{array}$ & & 41 & $6.5 \mathrm{E}-06$ \\
\hline IFP1-9 & IFP1 & 59.4 & 18.3 & Granite & 12.8 & & 49 & $6.0 \mathrm{E}-06$ \\
\hline IFP30-1 & Kothur & 91.4 & 11.6 & Quartz & & 6.5 & 91.4 & $5.6 \mathrm{E}-07$ \\
\hline IFP30-2 & Kothur & 45.7 & 29.9 & Granite & 20.6 & $\begin{array}{l}4.0 \text { (overlying } \\
\text { saprolite) }\end{array}$ & 41 & 2.8E-06 \\
\hline IFP30-3 & Kothur & 50.3 & 29.9 & Granite & 27.1 & $\begin{array}{l}2.7 \text { (overlying } \\
\text { saprolite) }\end{array}$ & 36.5 & 8.5E-08 \\
\hline IFP30-4 & Kothur & 50.3 & 29.9 & Granite & 29.2 & & 42 & 8.8E-06 \\
\hline IFP30-5 & Kothur & 77.7 & 17.4 & Quartz & & 20.2 & 77.7 & 5.1E-06 \\
\hline IFP30-6 & Kothur & 50.3 & 11.6 & Quartz & & $\begin{array}{r}6.8 \\
\end{array}$ & 50.3 & 5.1E-08 \\
\hline IFP30-7 & Kothur & 64.0 & 30.2 & Granite & 16.7 & $\begin{array}{l}8.8 \text { (overlying } \\
\text { saprolite) }\end{array}$ & 51.5 & 4.5E-07 \\
\hline IFP30-8 & Kothur & 50.0 & 42.7 & Granite & 28 & & 38 & 6.3E-06 \\
\hline IFP30-9 & Kothur & 59.4 & 30.5 & Quartz & & 39.5 & 50 & 1.1E-05 \\
\hline IFP30-10 & Kothur & 73.0 & 27.4 & Quartz & & 30 & 73 & 1.6E-05 \\
\hline IFP30-11 & Kothur & 74.0 & 12.2 & Quartz & & 25.5 & 36.5 & 1.30E-05 \\
\hline
\end{tabular}

830

831

832

833

834

835

836

837

838

839

840

841

842

Table 1.

\begin{tabular}{|l|l|r|r|r|r|r|c|}
\hline $\begin{array}{l}\text { Pumping } \\
\text { Wells }\end{array}$ & $\begin{array}{c}\text { Tested } \\
\text { aquifer * }\end{array}$ & $\begin{array}{c}\text { Well } \\
\text { radius } \\
(\mathrm{m})\end{array}$ & $\begin{array}{c}\text { Pumping } \\
\text { rate }\left(\mathrm{m}^{3} / \mathrm{h}\right)\end{array}$ & $\begin{array}{c}\text { Duration of } \\
\text { the test } \\
(\mathrm{min} .)\end{array}$ & $\begin{array}{c}\text { Max. dd. } \\
(\mathrm{m})^{* *}\end{array}$ & $\begin{array}{c}\text { Nb. of } \\
\text { obs. } \\
\text { wells } * * *\end{array}$ & Diagnosis \\
\hline IFP1-6 & granite & 0.11 & 13.5 & 1580 & 21.48 & 9 & Channelized flow \\
\hline IFP1-8 & granite & 0.11 & 3.5 & 1430 & 5.51 & 3 & One-no flow boundary \\
\hline IFP30-4 & granite & 0.11 & 6.8 & 1440 & 10.31 & 2 & Dual porosity \\
\hline IFP30-5 & quartz & 0.11 & 4.9 & 1440 & 8.33 & 7 & Partially penetrating well \\
\hline IFP30-10 & quartz & 0.11 & 16.3 & 2890 & 9.9 & 8 & Dual porosity \\
\hline
\end{tabular}

Table 2.

Dewandel et al. A conceptual hydrodynamic model of a geological discontinuity in hard rock aquifers:

example of a quartz reef in granitic terrain in South India 
843

\begin{tabular}{|c|c|c|c|c|c|c|c|c|}
\hline Well ID & & $r(m)$ & $s-m^{*}(m)$ & $\mathrm{K}(\mathrm{m} / \mathrm{s})$ & $S(-)$ & $\begin{array}{l}\text { Anisotropy } \\
\mathrm{Kx} / \mathrm{Kz}(-)\end{array}$ & $\begin{array}{l}\text { Aquifer } \\
\text { thickness } \\
\text { (m) }\end{array}$ & $\begin{array}{l}\text { Screened } \\
\text { thickness } \\
(\mathrm{m})^{\star \star *}\end{array}$ \\
\hline IFP30-5 & pump. well & 0.11 & 8.33 & 4.2E-06 & - & 3.1 & 110 & 35 \\
\hline IFP30-1 & obs.well & 30.1 & 1.12 & 3.6E-06 & 1.4E-03 & 3.5 & 140 & 10 \\
\hline IFP30-2 & obs.well & 27.3 & 2.13 & 2.6E-06 & 4.0E-04 & 2.0 & 130 & 40 \\
\hline IFP30-6 & obs.well & 96.2 & 0.44 & 3.4E-06 & $1.8 \mathrm{E}-03$ & 3.0 & 130 & 20 \\
\hline IFP30-7 & obs.well & 52.5 & 0.45 & $2.9 \mathrm{E}-06$ & 7.5E-03 & 10.0 & 110 & 50 \\
\hline IFP30-9 & obs.well & 88.0 & 1.18 & $5.1 \mathrm{E}-06$ & $4.5 \mathrm{E}-05$ & 1.0 & 100 & 100 \\
\hline IFP30-10 & obs.well & 135.5 & 1.06 & $5.5 \mathrm{E}-06$ & 2.7E-05 & 1.0 & 100 & 100 \\
\hline IFP30-11 & obs.well & 180.6 & 0.85 & $5.9 \mathrm{E}-06$ & 3.5E-05 & 1.0 & 100 & 100 \\
\hline IFP30-3 & obs.well & 62.5 & No reaction & - & - & - & - & - \\
\hline IFP30-4 & obs.well & 103.0 & No reaction & - & - & - & - & - \\
\hline IFP30-8 & obs.well & 118.0 & No reaction & - & - & - & - & - \\
\hline & & & Average $^{* *}$ & 4.0E-06 & 3.2E-04 & 3.1 & 115.0 & \\
\hline & & & Std.Dev $( \pm)$ & $1.2 \mathrm{E}-06$ & 2.7E-03 & 3.0 & 16.0 & \\
\hline
\end{tabular}

844

845

846

847

848

849

850

851

852

853

854

855

856

857

858

Table 3.

\begin{tabular}{|c|c|c|c|c|c|c|c|c|}
\hline Well & & $r(m)$ & s-max ${ }^{* *}(m)$ & $\mathrm{Kf}(\mathrm{m} / \mathrm{s})$ & $\mathrm{Km}(\mathrm{m} / \mathrm{s})$ & Sf $(-)$ & Sm (-) & Stot (-) \\
\hline IFP30/10 & pump. well & 0.11 & 9.9 & 6.3E-06 & 2.4E-09 & - & - & - \\
\hline IFP30/1 & obs.well & 123.2 & 3.38 & $8.5 \mathrm{E}-06$ & $4.5 \mathrm{E}-10$ & 4.9E-05 & 6.1E-05 & 1.1E-04 \\
\hline IFP30/2 & obs.well & 115.1 & 3.63 & $6.5 \mathrm{E}-06$ & $1.9 \mathrm{E}-09$ & $4.2 \mathrm{E}-05$ & $1.8 \mathrm{E}-04$ & $2 \mathrm{E}-04$ \\
\hline IFP30/5 & obs.well & 135.7 & 4.42 & $6.5 \mathrm{E}-06$ & $6.0 \mathrm{E}-10$ & $1.5 \mathrm{E}-05$ & 4.9E-05 & 6.4E-05 \\
\hline IFP30/6* & obs.well & 222.0 & 1.27 & $1.1 \mathrm{E}-05$ & $1.5 \mathrm{E}-09$ & $8.5 \mathrm{E}-05$ & 1.3E-04 & $2.1 \mathrm{E}-04$ \\
\hline IFP30/7* & obs.well & 145.0 & 1.04 & $6.0 \mathrm{E}-06$ & 8.0E-09 & $2.4 \mathrm{E}-04$ & 2.2E-03 & $2.5 \mathrm{E}-03$ \\
\hline IFP30/8 & obs.well & 92.0 & 0.18 & $2.1 \mathrm{E}-06$ & 2.6E-08 & $4.9 \mathrm{E}-03$ & $6.1 \mathrm{E}-02$ & $6.6 \mathrm{E}-02$ \\
\hline IFP30/9 & obs.well & 49.4 & 5.5 & $6.5 \mathrm{E}-06$ & 1.4E-09 & 2.6E-05 & $1.2 \mathrm{E}-04$ & 1.5E-04 \\
\hline IFP30/11 & obs.well & 57.8 & 4.97 & $6.2 \mathrm{E}-06$ & $5.5 \mathrm{E}-09$ & 5.2E-05 & 1.9E-04 & $2.4 \mathrm{E}-04$ \\
\hline IFP30/3 & obs.well & 132.8 & No reaction & - & - & - & - & - \\
\hline IFP30/4 & obs.well & 144.5 & No reaction & - & - & - & - & - \\
\hline & & & geomean $^{\star \star \star}$ & $6.2 \mathrm{E}-06$ & 2.4E-09 & 8.9E-05 & $3.5 \mathrm{E}-04$ & 4.6E-04 \\
\hline & & & StDev $( \pm)$ & 2.4E-06 & 8.2E-09 & $1.7 \mathrm{E}-03$ & $2.1 \mathrm{E}-02$ & $2.3 \mathrm{E}-02$ \\
\hline
\end{tabular}

Table 4.

\begin{tabular}{|c|c|c|c|c|c|c|c|c|}
\hline Well & WTFM & $r(m)$ & $s-m a x^{*}(m)$ & $\mathrm{Kf}(\mathrm{m} / \mathrm{s})$ & $\mathrm{Km}(\mathrm{m} / \mathrm{s})$ & $\mathrm{Sf}(-)$ & Sm (-) & Stot (-) \\
\hline IFP30/4 & pump. well & 0.11 & 10.31 & 6.4E-06 & 4.0E-09 & - & - & - \\
\hline IFP30/3 & obs.well & 40.6 & 1.08 & $6.5 \mathrm{E}-06$ & $7.0 \mathrm{E}-09$ & 9.5E-05 & $6.7 \mathrm{E}-03$ & $6.8 \mathrm{E}-03$ \\
\hline IFP30/8 & obs.well & 59.8 & 0.52 & $6.3 \mathrm{E}-06$ & $9.0 \mathrm{E}-10$ & $1.6 \mathrm{E}-04$ & $7.6 \mathrm{E}-03$ & $7.8 \mathrm{E}-03$ \\
\hline & & & geomean** & $6.4 \mathrm{E}-06$ & 2.9E-09 & $1.2 \mathrm{E}-04$ & $7.1 \mathrm{E}-03$ & 7.2E-03 \\
\hline & & & StDev $( \pm)$ & $1.0 \mathrm{E}-07$ & $3.0 \mathrm{E}-09$ & $4.5 \mathrm{E}-05$ & $6.7 \mathrm{E}-04$ & 7.2E-04 \\
\hline
\end{tabular}

Table 5.

Dewandel et al. A conceptual hydrodynamic model of a geological discontinuity in hard rock aquifers:

example of a quartz reef in granitic terrain in South India 
859

860

\begin{tabular}{|c|c|c|c|c|c|c|c|}
\hline & & & & & & NO flow Limit_d1 & NO flow Limit_d2 \\
\hline Well ID & & $r(m)$ & s-max* & $\mathrm{K}(\mathrm{m} / \mathrm{s})$ & S (-) & dist. $(\mathrm{m})$ & dist. (m) \\
\hline IFP1-6 & $\begin{array}{l}\text { pump. } \\
\text { well }\end{array}$ & 0.11 & 21.48 & $5.1 \mathrm{E}-06$ & - & 20 ** & $46^{* *}$ \\
\hline IFP1 & obs.well & 18.6 & 20.28 & $4.0 \mathrm{E}-06$ & 7.0E-05 & $31(10)^{* * *}$ & $138(41)^{* * *}$ \\
\hline IFP1-1 & obs.well & 28.2 & 11.87 & $6.0 \mathrm{E}-06$ & $4.2 \mathrm{E}-04$ & 35 & 47 \\
\hline IFP1-2 & obs.well & 40.4 & 9.28 & $5.4 \mathrm{E}-06$ & $1.6 \mathrm{E}-04$ & - & 42 \\
\hline IFP1-5 & obs.well & 17.7 & 12.69 & $7.9 \mathrm{E}-06$ & $1.7 \mathrm{E}-02$ & 25 & 44 \\
\hline IFP1-7 & obs.well & 8.7 & 14.05 & 3.3E-06 & $1.1 \mathrm{E}-03$ & 16 & - \\
\hline IFP1-9 & obs.well & 11.5 & 16.44 & 3.0E-06 & $2.6 \mathrm{E}-03$ & 13 & 42 \\
\hline IFP1-3 & obs.well & 61.5 & 0.75 & 3.3E-06 & 8.3E-04 & 18 & 43 \\
\hline IFP1-4 & obs.well & 40.4 & 0.3 & $4.8 E-05$ & $2.6 E-02$ & - & - \\
\hline IFP1-8 & obs.well & 51.7 & 0.1 & $1.0 E-04$ & $6.3 E-02$ & & - \\
\hline BW1 & obs.well & 69.3 & No reaction & - & - & - & - \\
\hline BW2 & obs.well & 95.4 & No reaction & - & - & - & - \\
\hline & & & Average $\mathrm{e}^{\star \star \star \star}$ & 4.5E-06 & 7.8E-04 & 19.5 & 44.3 \\
\hline & & & StDev $( \pm)$ & $1.7 \mathrm{E}-06$ & $6.0 \mathrm{E}-03$ & 8.8 & 2.1 \\
\hline
\end{tabular}

861 Table 6.

862 
864

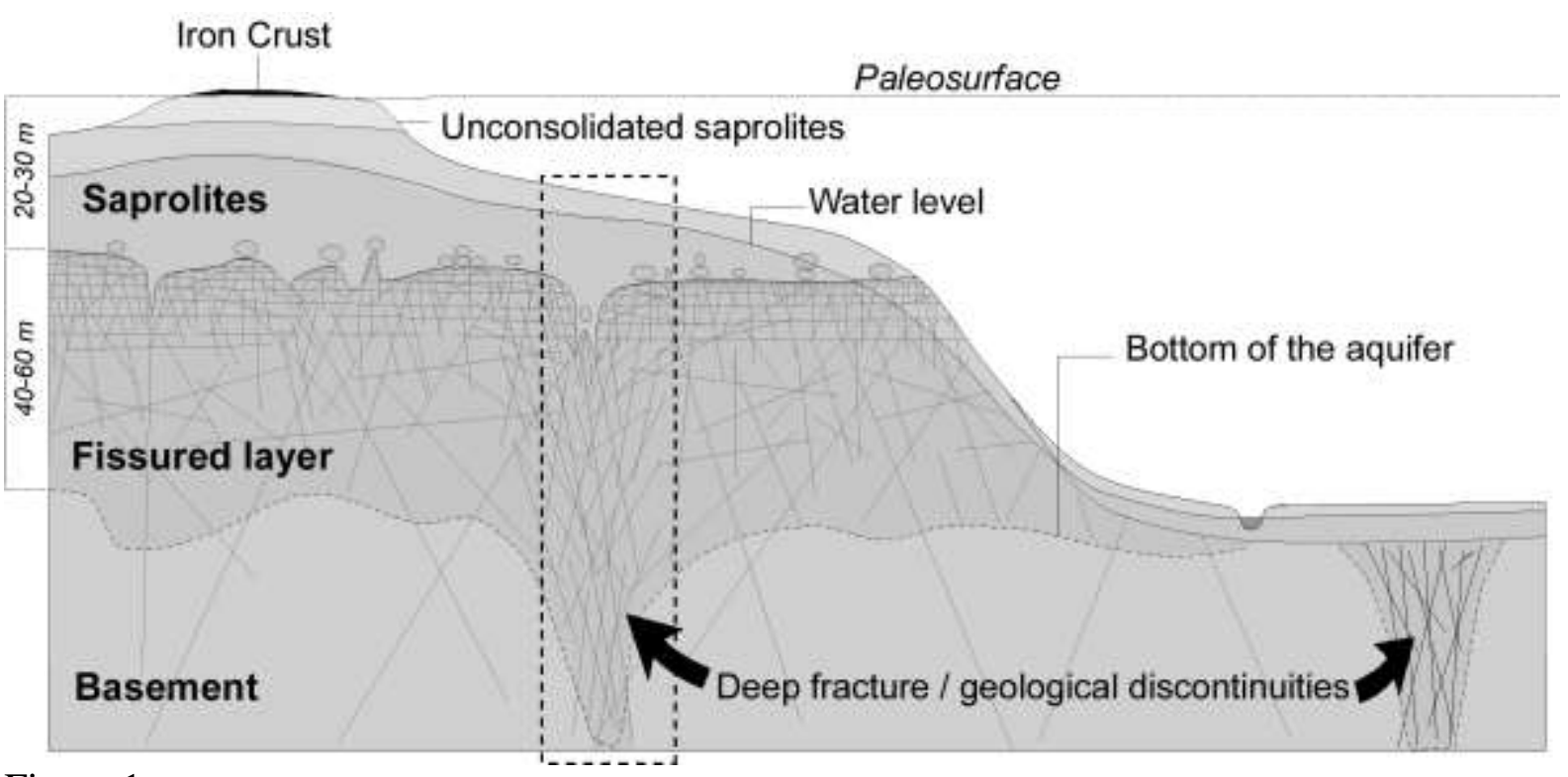

865

866

867
Figure 1
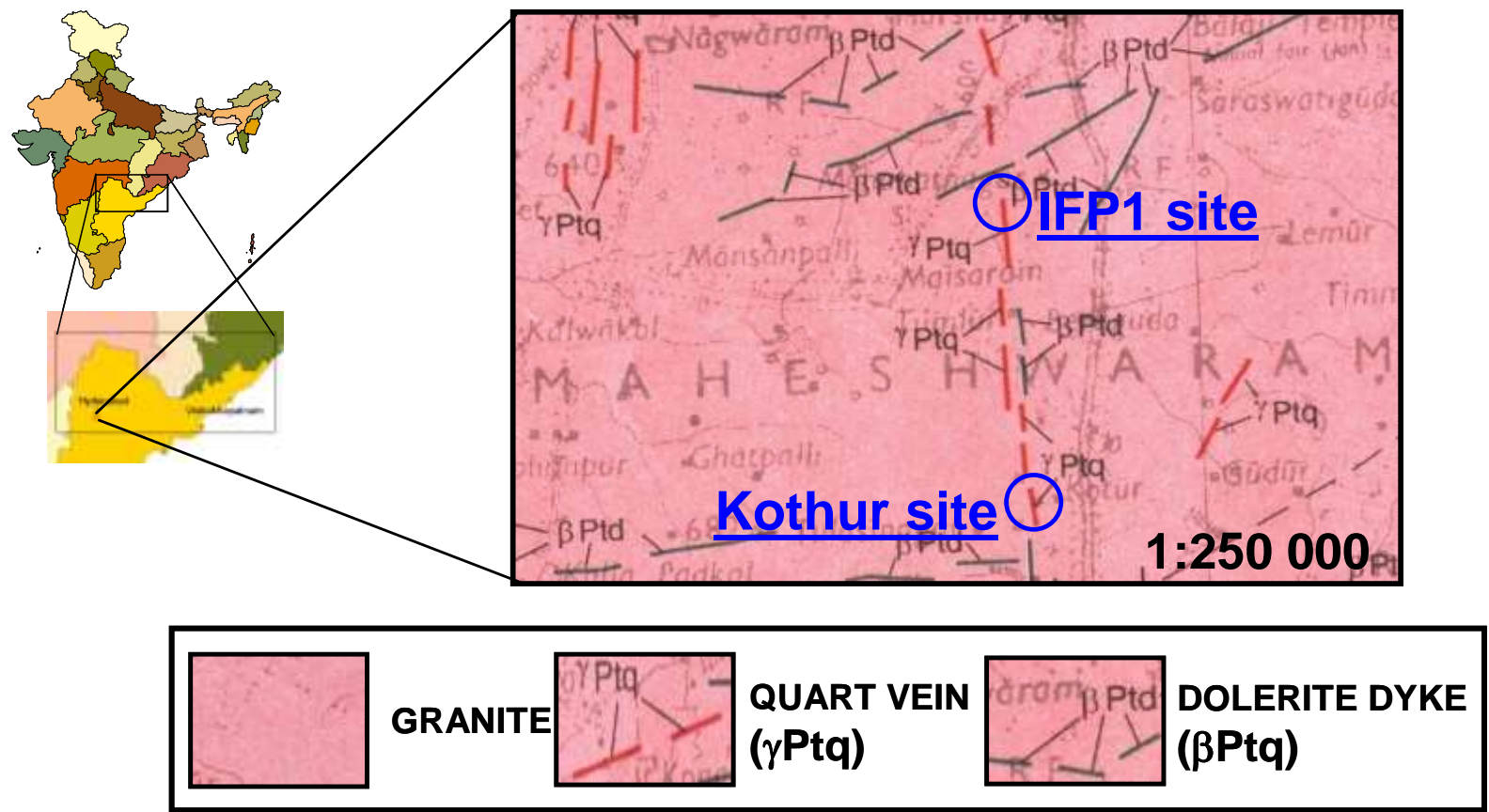


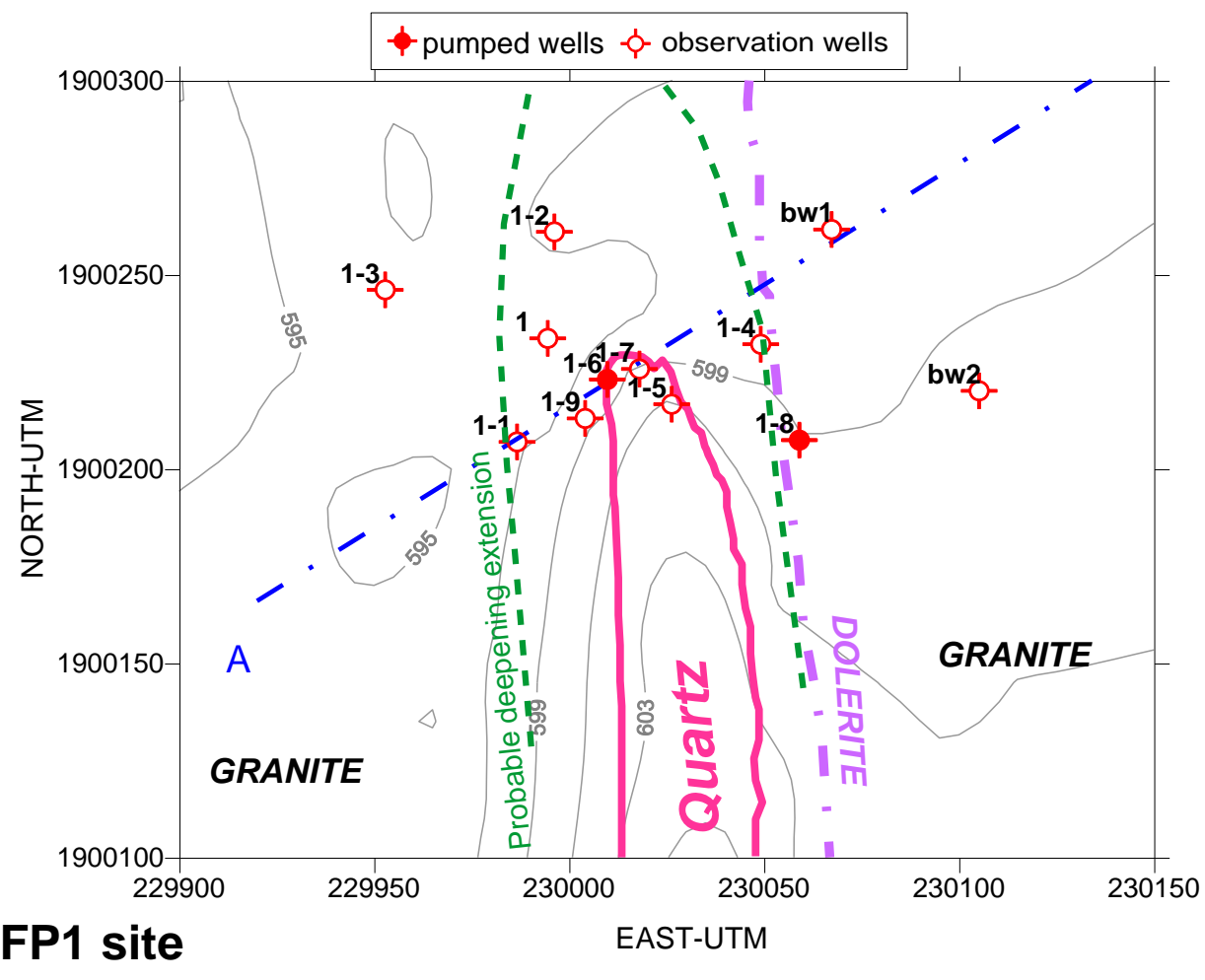

a) IFP1 site

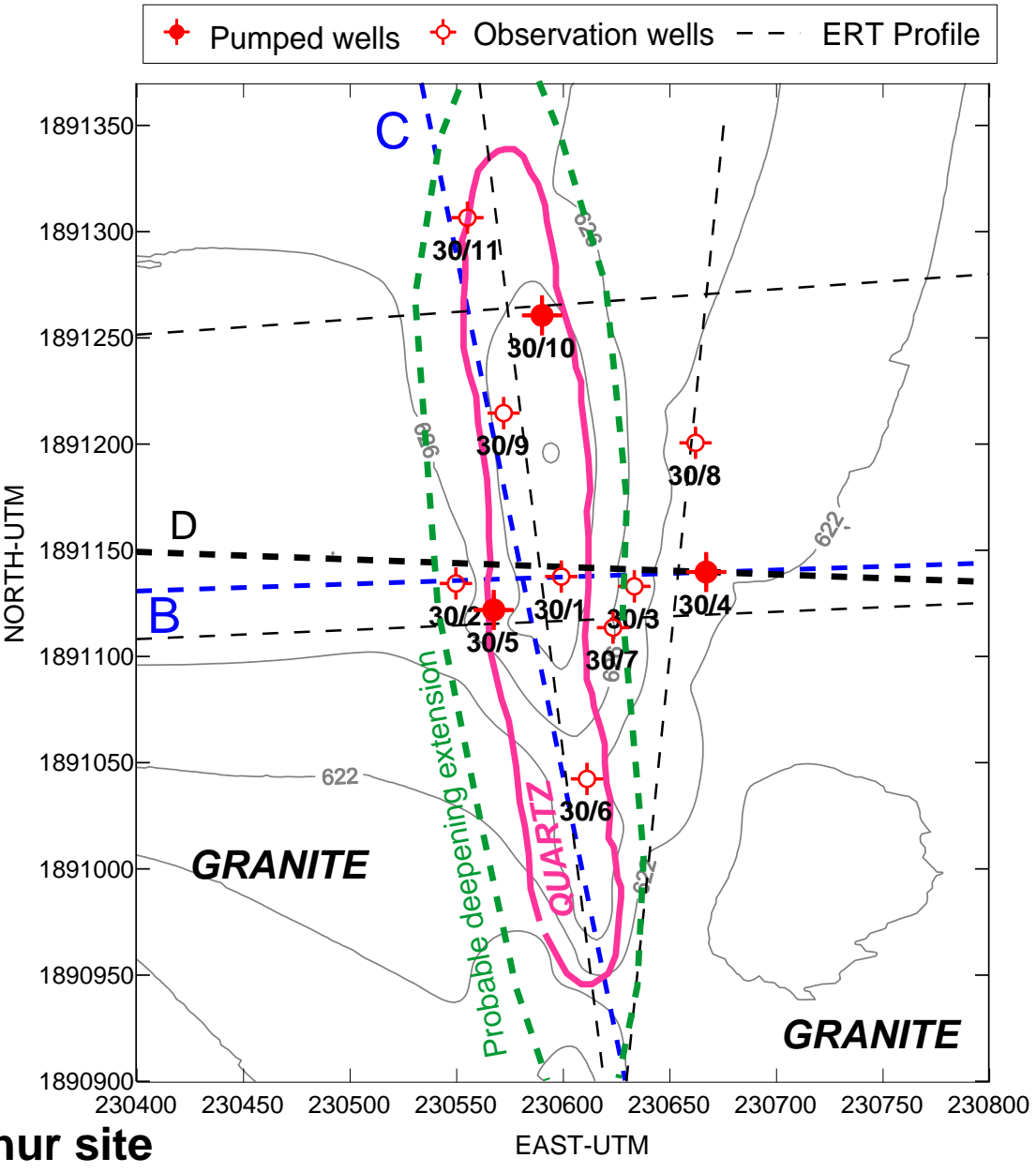




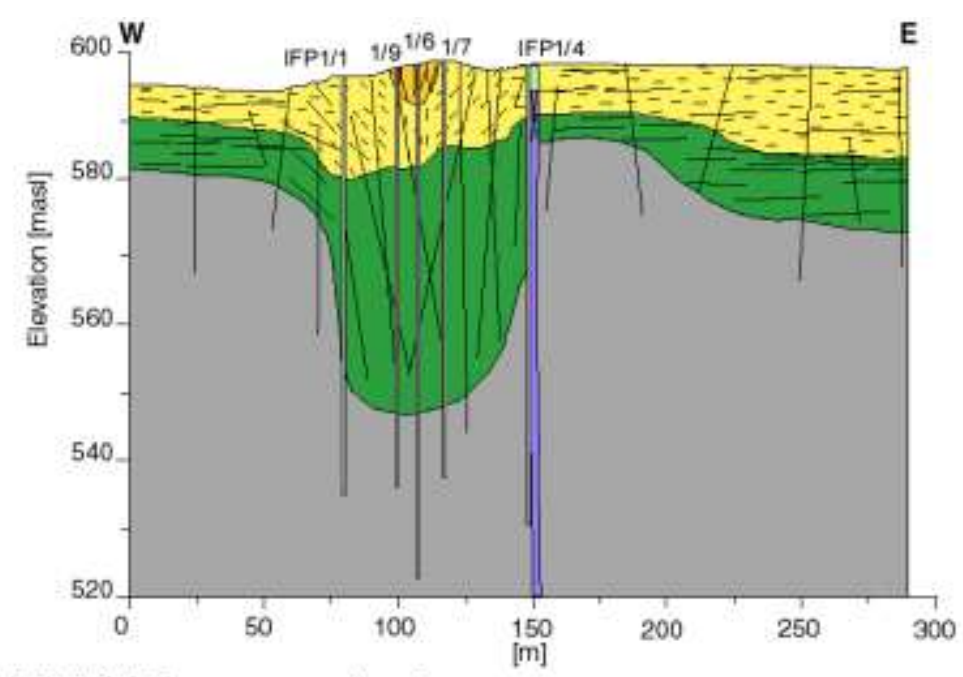

a) IFP 1 SITE - cross section A

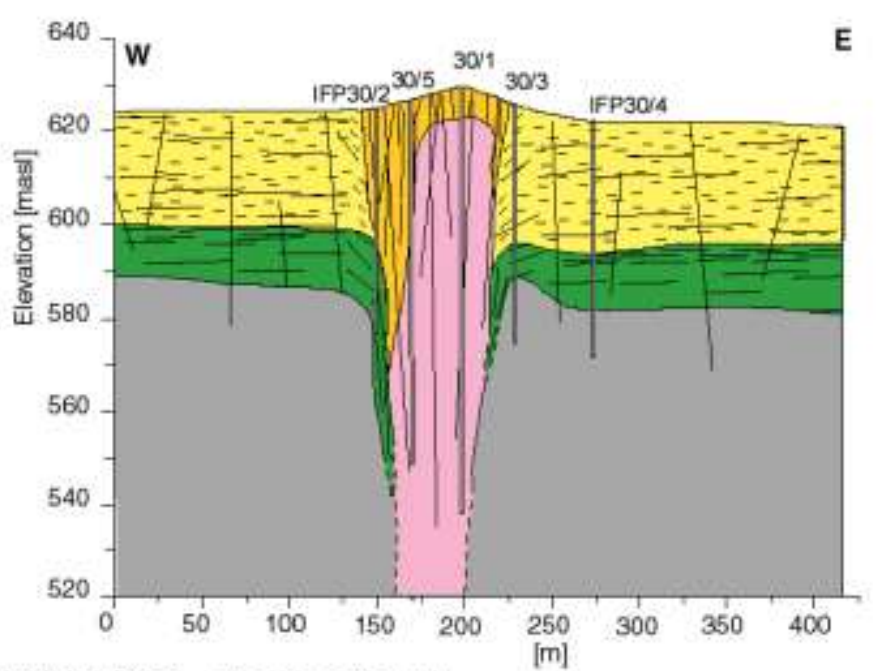

Legend

b) KOTHUR SITE - cross section B

\begin{tabular}{|c|c|}
\hline \multicolumn{2}{|c|}{$\begin{array}{l}\text { Orthogneissic pink granite } \\
\text { (porphyritic K-feldspar) }\end{array}$} \\
\hline$E$ & laminated saprolite \\
\hline$\approx$ & fissured layer \\
\hline$\square$ & unfissured granite \\
\hline Quart & \\
\hline$\square$ & weathered -fissured \\
\hline$\square$ & fresh -poorly fissured \\
\hline Doleri & $\begin{array}{l}\text { rite } \\
\text { weathered-clay }\end{array}$ \\
\hline$\square$ f & fresh \\
\hline
\end{tabular}

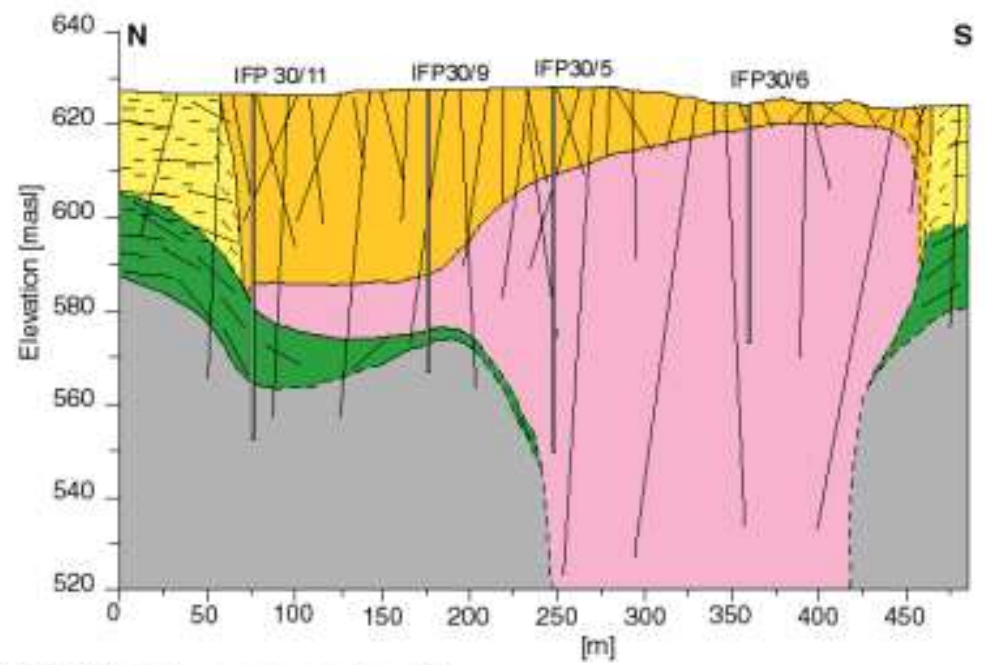

c) KOTHUR SITE - cross section C

Figure 4. 


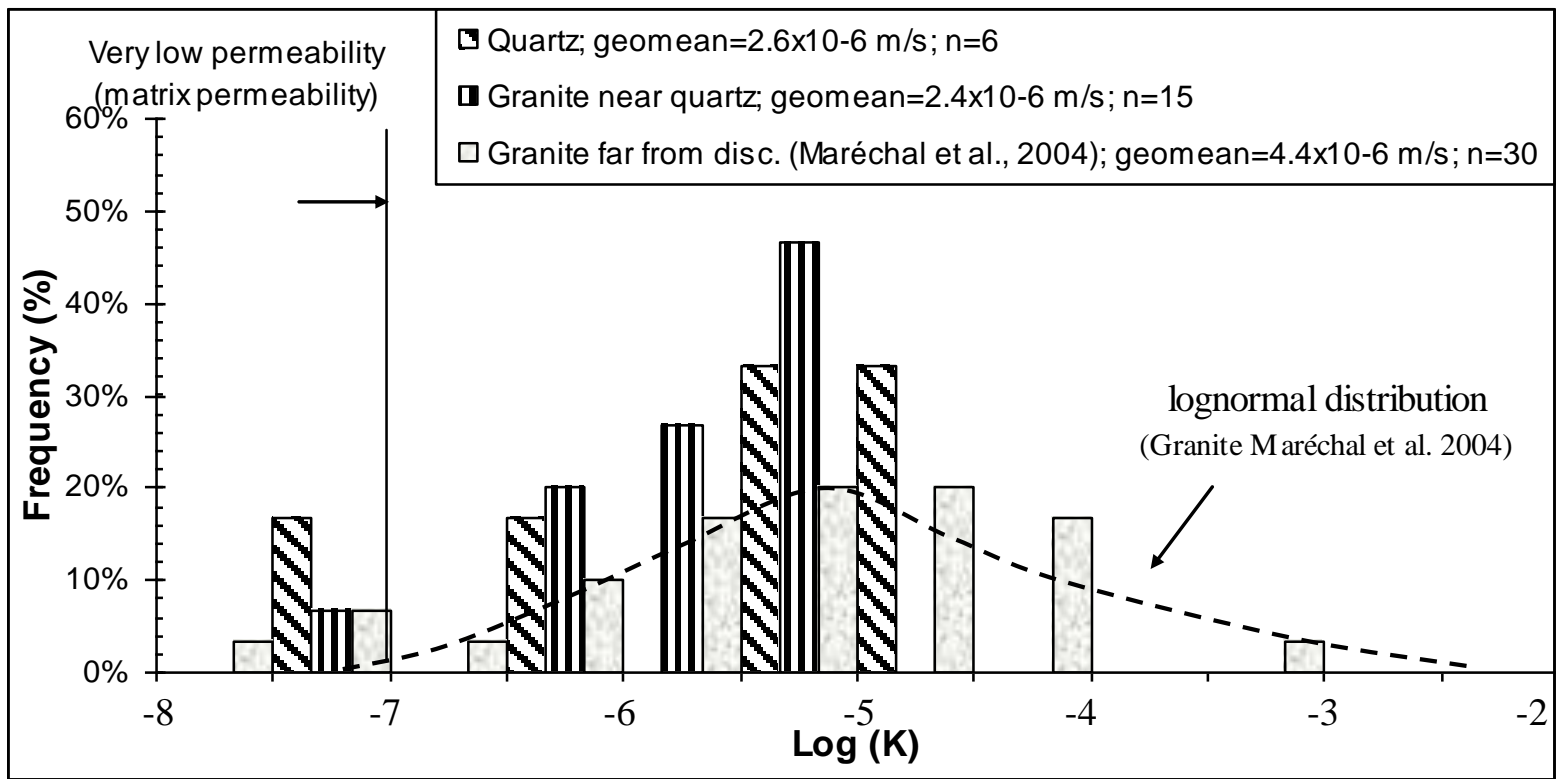

Figure 5. 


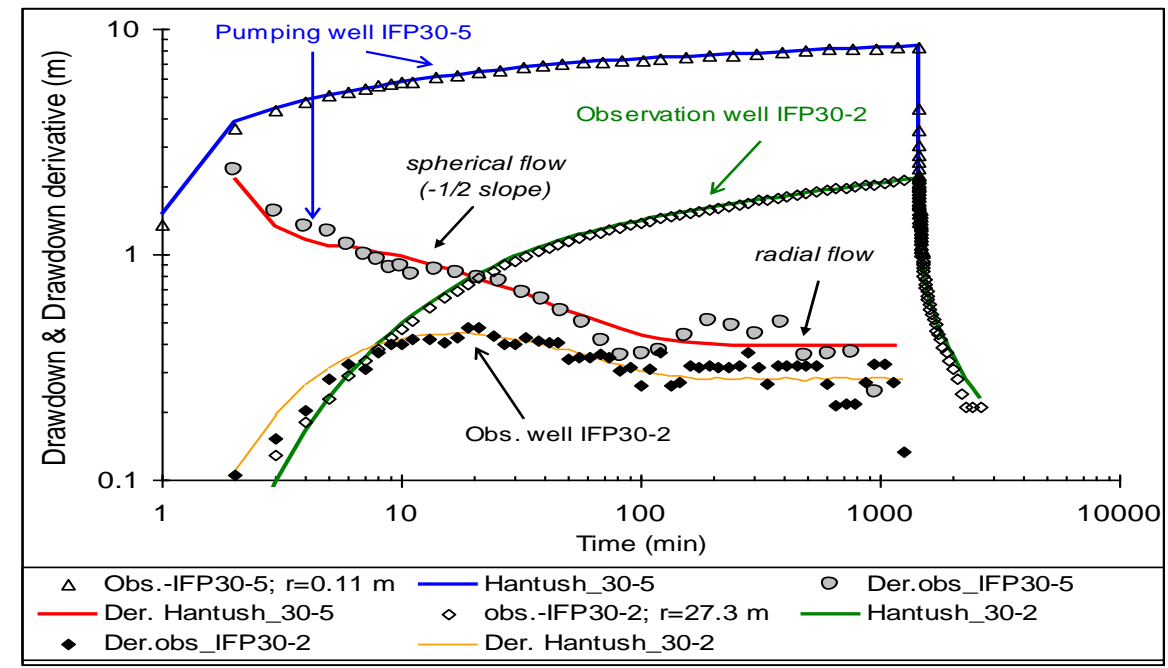

a) IPF30-5

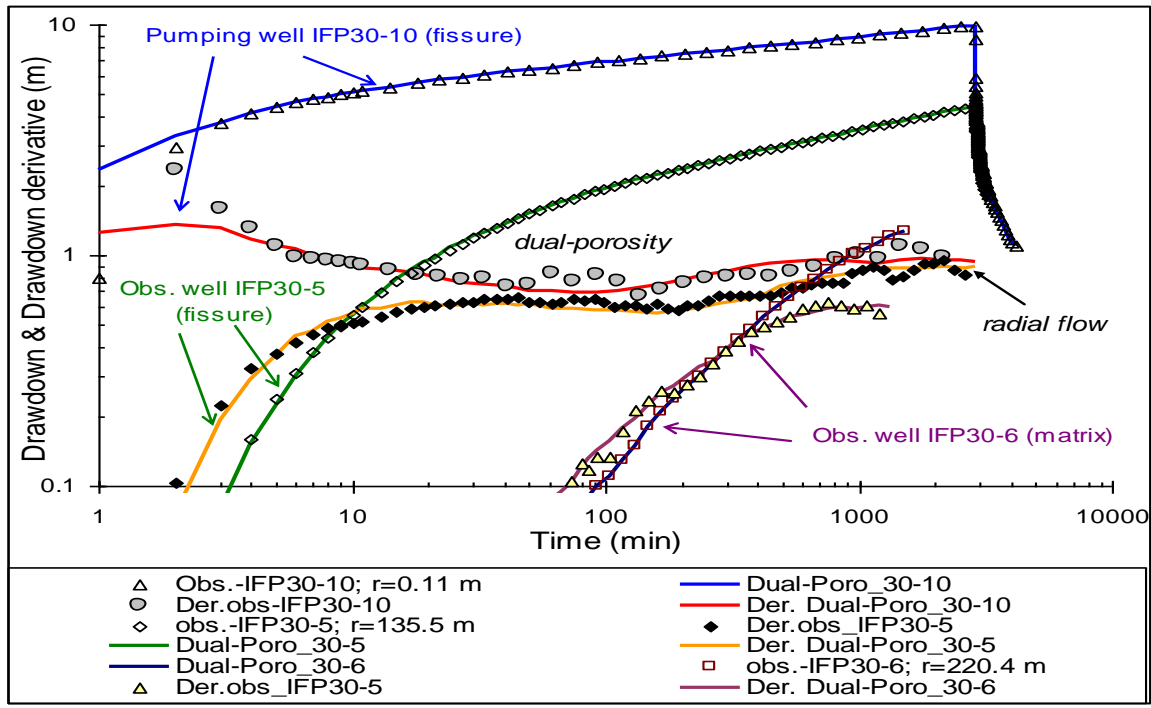

b) IPF30-10

c) IPF1-6

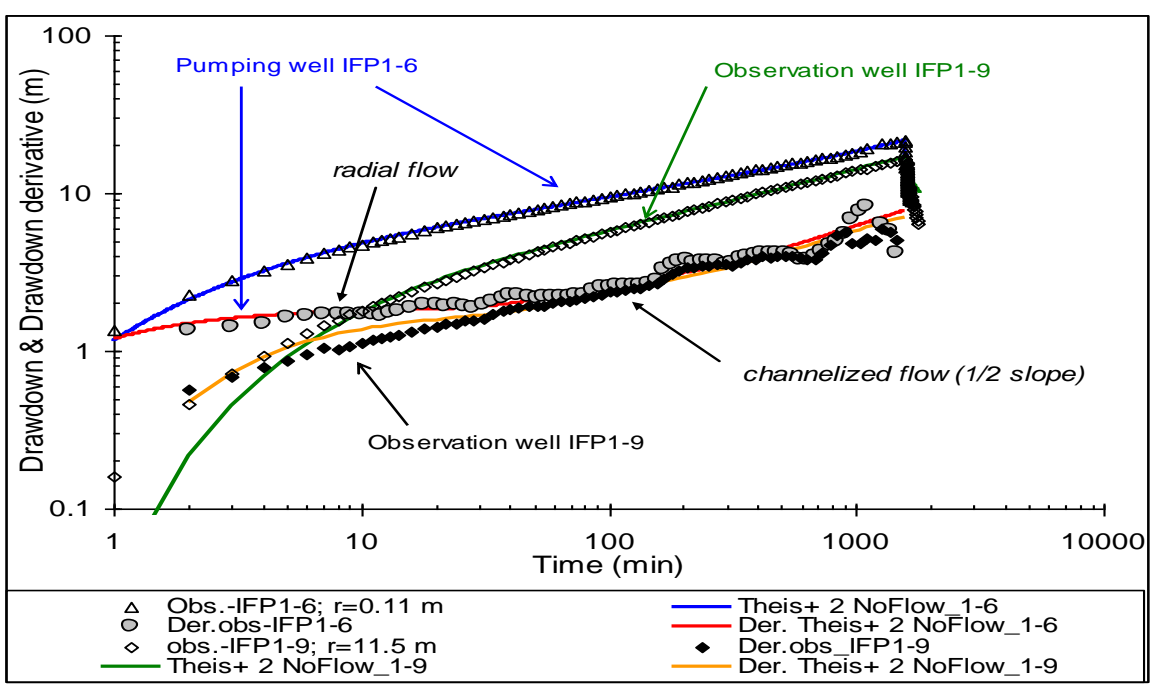

894 Figure 6. 


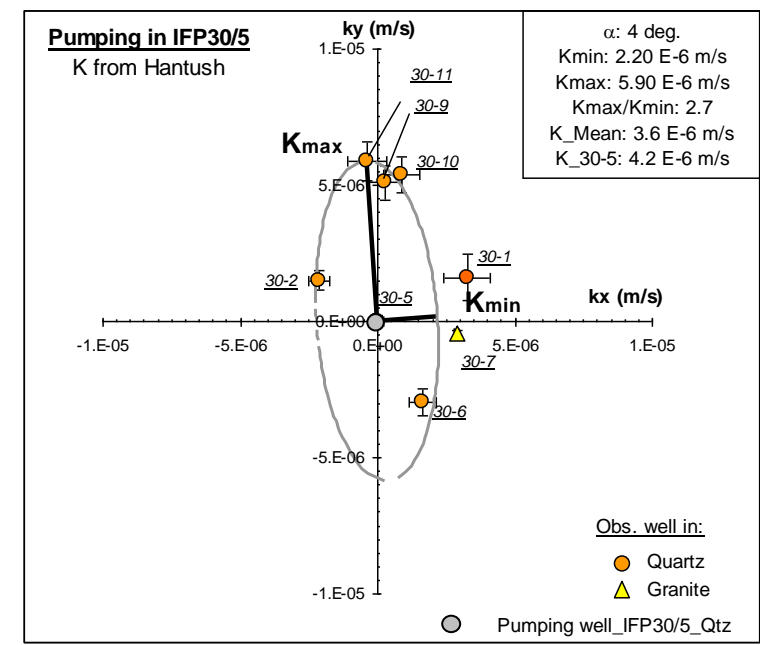

a) IFP30-5 -Kothur site

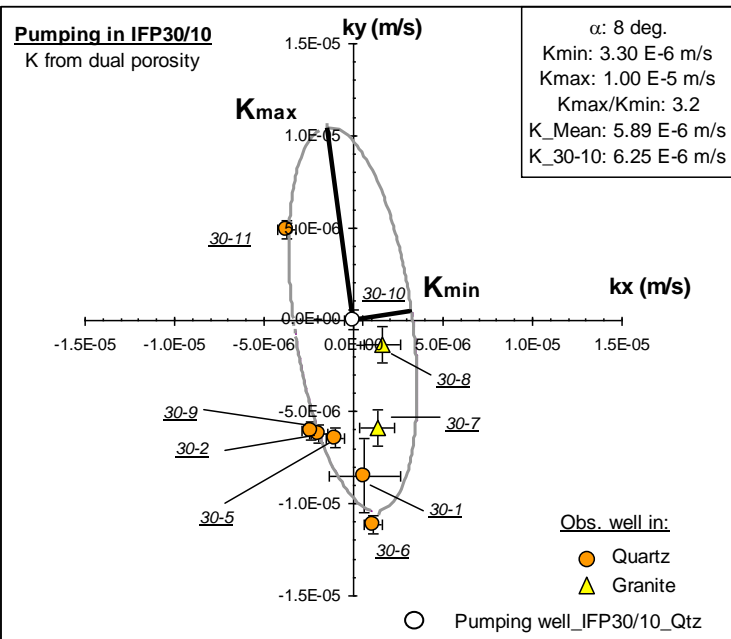

b) IFP30-10 -Kothur site

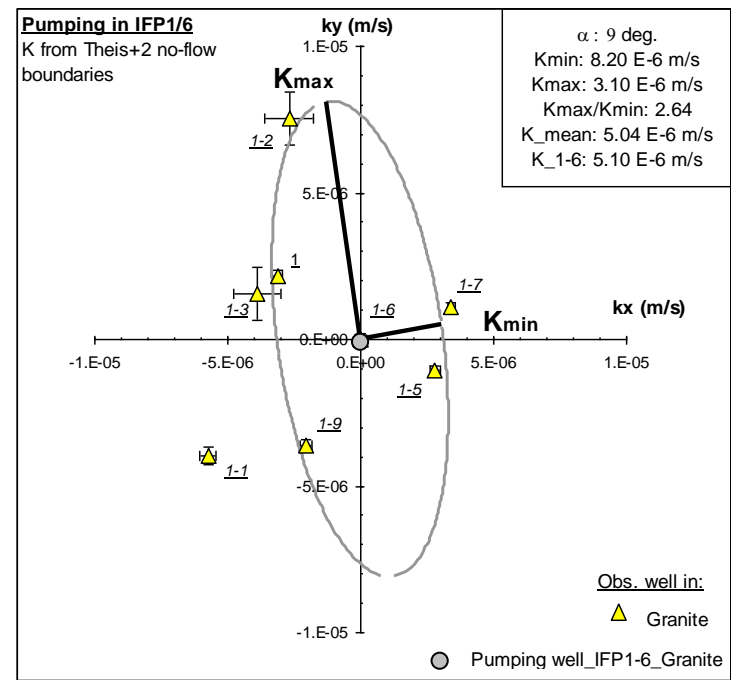

Figure 7. 
Fissured / weathered quartz

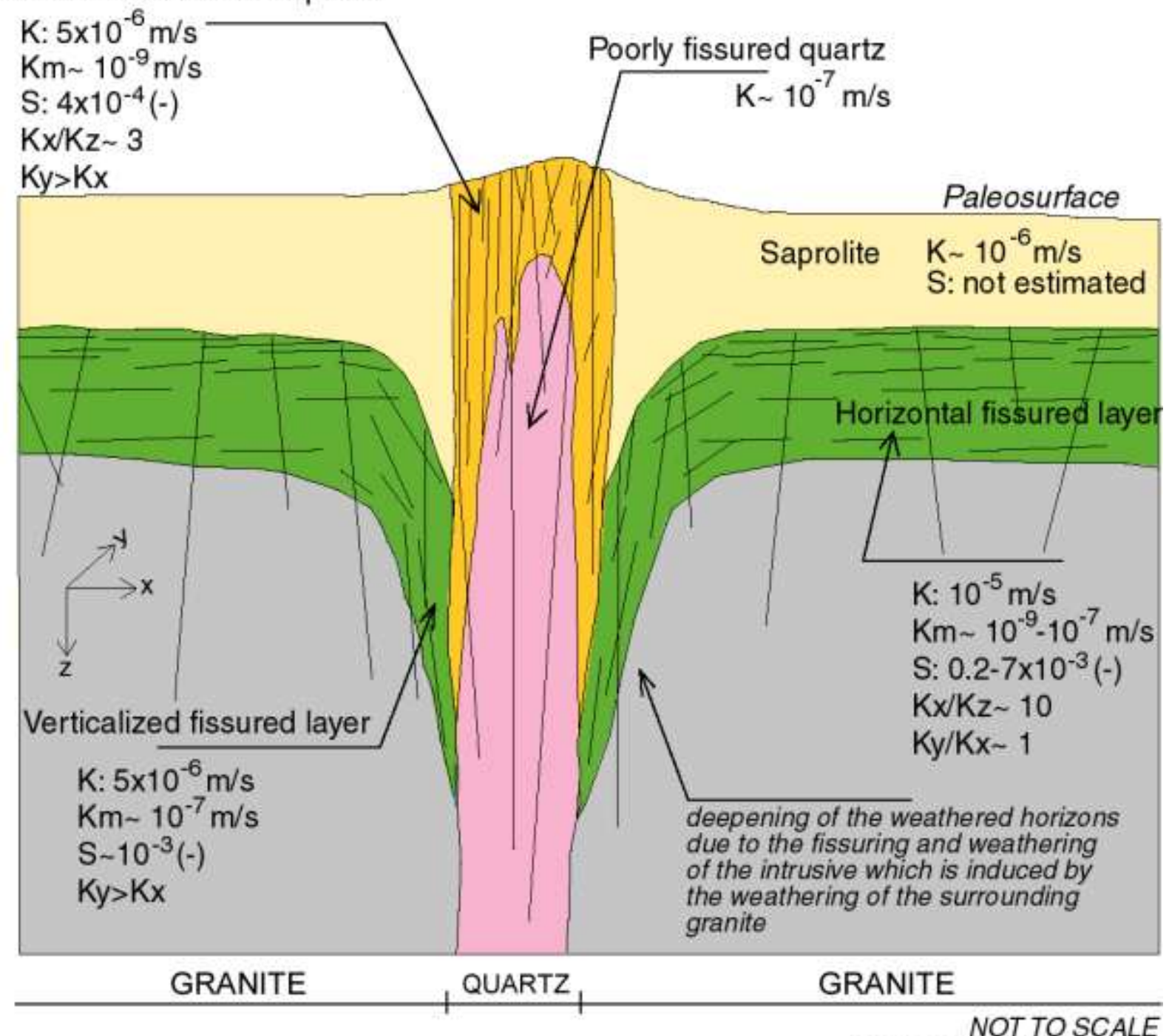

Figure 8.

Ky: parallel to the reef axis Kz: according to depth 